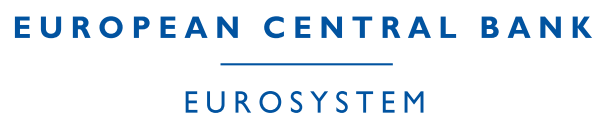

\title{
THE BUSINESS CYCLE IMPLICATIONS OF BANKS' \\ MATURITY TRANSFORMATION
}

\author{
Martin M. Andreasen, \\ Marcelo Ferman \\ and Pawel Zabczyk
}
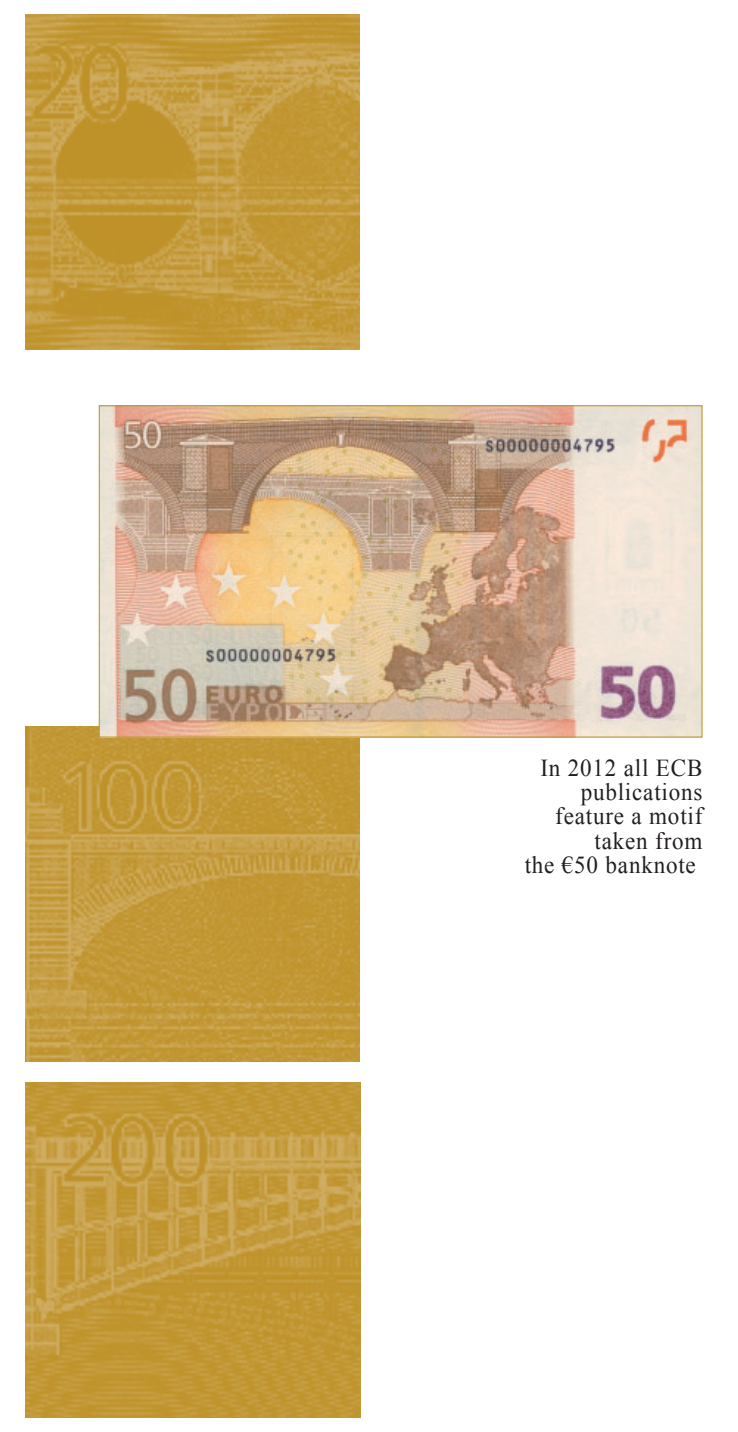

MACROPRUDENTIAL RESEARCH NETWORK

NOTE: This Working Paper should not be reported as representing the views of the European Central Bank (ECB). The views expressed are those of the authors and do not necessarily reflect those of the ECB. 


\section{Macroprudential Research Network}

This paper presents research conducted within the Macroprudential Research Network (MaRs). The network is composed of economists from the European System of Central Banks (ESCB), i.e. the 27 national central banks of the European Union (EU) and the European Central Bank. The objective of MaRs is to develop core conceptual frameworks, models and/or tools supporting macro-prudential supervision in the EU.

The research is carried out in three work streams: 1) Macro-financial models linking financial stability and the performance of the economy; 2) Early warning systems and systemic risk indicators; 3) Assessing contagion risks.

MaRs is chaired by Philipp Hartmann (ECB). Paolo Angelini (Banca d'Italia), Laurent Clerc (Banque de France), Carsten Detken (ECB), Cornelia Holthausen (ECB) and Katerina Šmídková (Czech National Bank) are workstream coordinators. Xavier Freixas (Universitat Pompeu Fabra) and Hans Degryse (Katholieke Universiteit Leuven and Tilburg University) act as external consultant. Angela Maddaloni (ECB) and Kalin Nikolov (ECB) share responsibility for the MaRs Secretariat. The refereeing process of this paper has been coordinated by a team composed of Cornelia Holthausen, Kalin Nikolov and Bernd Schwaab (all ECB).

The paper is released in order to make the research of MaRs generally available, in preliminary form, to encourage comments and suggestions prior to final publication. The views expressed in the paper are the ones of the author(s) and do not necessarily reflect those of the ECB or of the ESCB.

\section{Acknowledgements}

We thank Mark Gertler, Peter Karadi, Kalin Nikolov, Matthias Paustian, Gianluca Violante and participants at the conference hosted by the Bank of England and the European Central Bank on "Corporate Credit and The Real Economy: Issues and Tools Relevant for Monetary Policy Analysis” December 82010 for helpful comments and discussions. The views expressed in this paper do not represent those of the Bank of England or the Monetary Policy Committee.

\section{Martin M. Andreasen}

at Aarhus University, Nordre Ringgade 1, 8000 Aarhus, Denmark and CREATES; email: mmandreasendk@gmail.com

\section{Marcelo Ferman (Corresponding author)}

at LSE, Houghton Street, London, WC2A 2AE, UK; e-mail: m ferman1@lse.ac.uk

\section{Pawel Zabczyk}

at Bank of England, Threadneedle Street, City of London, EC2R 8AH, UK; e-mail: pawel.zabczyk@bankofengland.co.uk

\section{(C) European Central Bank, 2012}

\section{Address}

Kaiserstrasse 29, 60311 Frankfurt am Main, Germany

Postal address

Postfach 1603 19, 60066 Frankfurt am Main, Germany

\section{Telephone}

+496913440

\section{Internet}

http://www.ecb.europa.eu

\section{Fax}

+496913446000

All rights reserved.

ISSN 1725-2806 (online)

Any reproduction, publication and reprint in the form of a different publication, whether printed or produced electronically, in whole or in part, is permitted only with the explicit written authorisation of the ECB or the authors.

This paper can be downloaded without charge from http://www.ecb.europa.eu or from the Social Science Research Network electronic library at $h$ ttp://ssrn.com/abstract_id=1569365. 


\begin{abstract}
This paper develops a DSGE model where banks use short-term deposits to provide firms with long-term credit. The demand for long-term credit arises because firms borrow in order to finance their capital stock which they only adjust at infrequent intervals. Within an RBC framework, we show that maturity transformation in the banking sector dampens the consumption and investment response to a technology shock. Our model also implies that the average deposit rate is less persistent than the average long-term loan rate, which we show is in line with corporate interest rate data in the US.
\end{abstract}

Keywords: Banks, DSGE model, Financial frictions, Long-term credit, Maturity transformation

JEL: E32, E44, E22, G21. 


\section{Non-technical summary}

The recent economic crisis highlighted the importance of financial factors in the propagation of economic disturbances. While some analyses, most notably the well-known studies by Kiyotaki and Moore and Bernanke, Gertler and Gilchrist have studied the role of financial frictions, they did so without explicitly modelling the behaviour of the banking sector. A growing number of papers has therefore incorporated this sector into general equilibrium models. With a few exceptions, however, this literature abstracts from a key aspect of banks' behaviour - ie, the fact that banks fund themselves using short-term deposits while providing long-term credit. This so-called 'maturity transformation' has the potential to affect the propagation of stochastic shocks, and the aim of this paper is to propose a DSGE model which helps to clarify how.

A general equilibrium approach is essential for our analysis, because we are interested not only in explaining how long-term credit affects the economy but also in the important feedback effects from the rest of the economy to banks and their credit supply. There are, however, several technical difficulties which mean that maturity transformation based on long-term credit has not been widely studied in a DSGE set up. The framework we propose overcomes these difficulties and remains conveniently tractable. We assume, in particular, that firms need credit to purchase their capital stock and that they change their level of capital at random intervals - meaning they require financing for longer periods of time.

Importantly, we show that this set up, by itself, has no implications for shock propagation. This means that the aggregate effects of maturity transformation we obtain are not a trivial implication of the infrequent capital adjustment assumption. It is only when we introduce banks, which use accumulated wealth and short-term deposits from the household sector to provide longer-term credit to firms, that maturity transformation starts playing a role.

We then illustrate the quantitative implications of maturity transformation in a real DSGE model, where shocks affecting productivity are the only source of fluctuations. Our analysis highlights the existence of a credit maturity attenuator effect, meaning that the response of output to technology shocks decreases with higher degrees of maturity transformation. Our model also implies that the average deposit rate is less persistent than the average long-term loan rate, which we show is in line with corporate interest rate data in the US.

Fundamentally, a positive unexpected change in firm productivity has a smaller effect on 
output because banks' revenues respond less to the shock. In particular, many loans will have been granted prior to the shock, and cannot be adjusted quickly. This smaller increase in banks' net worth means that the increase in the amount of credit they can supply will also be smaller, constraining the increase in output - relative to the case of no maturity mismatch and no long-term lending.

The attenuating result we derive may seem surprising, as it contrasts with the potentially destabilising effects of a maturity mismatch discussed in the seminal study of Diamond and Dybvig (1983) and subsequent research. Arguably, there is no contradiction, however, because the introduction of deposit insurance in our model eliminates the unstable and Pareto-inferior bank-run equilibrium considered previously. Our results can thus be seen as describing a world in which a sovereign / deposit insurance agency can always credibly commit to intervene, thus severing the link between the performance of the economy and financial stability. It follows, that such tantalising two-way links could be introduced by considering illiquidity or insolvency risks due to lack of perfect insurance. Our work, and specifically developing a dynamic model with maturity transformation, can be seen as a first step in that direction, or, alternatively, as a description of the limiting case, in which regulation has eliminated all of the well-known destabilising effects of maturity mismatches. We believe that quantifying the dynamic impact of those effects and articulating the trade-offs associated with insurance provision would both make for interesting extensions. 


\section{Introduction}

The seminal contributions by Kiyotaki \& Moore (1997), Carlstrom \& Fuerst (1997), and Bernanke et al. (1999) show how financial frictions augment the propagation of shocks in otherwise standard real business cycle (RBC) models. ${ }^{1}$ This well-known financial accelerator effect is derived without explicitly modelling the behaviour of the banking sector and a growing literature has therefore incorporated this sector into a general equilibrium framework. ${ }^{2}$ With a few exceptions, this literature assumes that banks receive one-period deposits which are instantaneously passed on to firms as one-period credit. Hence, most papers do not address a key aspect of banks' behaviour, namely the transformation of short-term deposits into long-term credit.

The aim of this paper is to examine how long-term credit and maturity transformation affect business cycle dynamics. Our main contribution is to show how these features may be introduced in otherwise standard dynamic stochastic general equilibrium (DSGE) models, including the models by Christiano et al. (2005) and Smets \& Wouters (2007). We then illustrate the quantitative effects of long-term credit and maturity transformation in a simple RBC model.

Some implications of maturity transformation have been studied outside a general equilibrium framework. For instance, Flannery \& James (1984), Vourougou (1990), and Akella \& Greenbaum (1992) document that the asset price of a bank with a large maturity mismatch on its balance sheet reacts more to unanticipated interest rate changes than the asset price of a bank with a small maturity mismatch. Additionally, the papers by Gambacorta \& Mistrulli (2004) and den Heuvel (2006) argue that banks' maturity transformation also affects the transmission mechanism of a monetary policy shock. In our context, however, a general equilibrium framework is necessary because we are interested not only in explaining effects of long-term credit on the economy but also the important feedback effects from the rest of the economy to banks and their credit supply.

Maturity transformation based on long-term credit has to our knowledge not been studied in a general equilibrium setting before, although long-term financial contracts have been examined by Gertler (1992) and Smith \& Wang (2006). ${ }^{3}$ This may partly be explained by the fact that

\footnotetext{
${ }^{1}$ See also Berger \& Udell (1992), Peek \& Rosengren (2000), Hoggarth et al. (2002), Dell'Ariccia et al. (2008), Chari et al. (2008), Campello et al. (2009) for a discussion of the real impact of financial shocks.

${ }^{2}$ See for instance Chen (2001), Aikman \& Paustian (2006), Goodfriend \& McCallum (2007), Teranishi (2008), Gertler \& Karadi (2009), Gertler \& Kiyotaki (2009), and Gerali et al. (2009).

${ }^{3}$ The paper by Gertler \& Karadi (2011) implicitly allows for maturity transformation by letting banks receive
} 
introducing long-term credit and maturity transformation in a general equilibrium framework is quite challenging for at least three reasons. Firstly, one needs to rationalise why firms demand long-term credit. Secondly, banks' portfolios of outstanding loans are difficult to keep track of with long-term credit. Finally, and related to the second point, model aggregation is often very difficult or simply infeasible when banks provide long-term credit.

The framework we propose overcomes these three difficulties and remains conveniently tractable. Our key assumption is to consider the case where firms in every period face a constant probability $\alpha_{k}$ of being unable to adjust their capital stock. The capital level of firms that cannot adjust their capital level is assumed to remain constant until they get the chance to re-optimise. This friction makes it reasonable to assume that firms demand long-term credit when we impose the standard requirement that firms borrow to finance their capital stock. That is, firms require a fixed amount of credit for potentially several periods because they may be unable to adjust their capital level for several periods in the future.

Our setup matches the stylised fact that firms invest in a lumpy fashion as studied in the literature on non-convex investment adjustment costs (Caballero \& Engel 1999, Cooper \& Haltiwanger 2006). However, for a wide class of DSGE models without a banking sector, we show that the dynamics of prices and aggregate variables are unaffected by this type of infrequent capital adjustments. That is, our model implies exactly the same dynamics for these variables as one in which firms change capital every period. This result relies on homogenous capital across firms and a Cobb-Douglas production function, which makes the size of each firm irrelevant for all prices and aggregate quantities. We refer to this result as the 'irrelevance of infrequent capital adjustments'. This is an important finding because it shows that the constraint we impose on firms' ability to adjust capital does not affect the aggregate properties of many DSGE models. Accordingly, the aggregate effects of long-term credit and maturity transformation in our model with a banking sector are not a trivial implication of infrequent capital adjustments.

A banking sector is introduced in our model along the lines suggested by Gertler \& Kiyotaki (2009) and Gertler \& Karadi (2011). That is, banks receive short-term deposits from the household sector and face an agency problem in the relationship with households. In contrast to Gertler \& Kiyotaki (2009) and Gertler \& Karadi (2011), we let banks' assets consist of longone-period deposits and invest in firms' equity, which has infinite maturity. 
term credit contracts supplied to firms. As we match the life of credit contracts to the number of periods firms do not adjust capital, the average life of banks' assets in the economy as a whole is $\mathcal{D} \equiv 1 /\left(1-\alpha_{k}\right)$. When $\alpha_{k}>0$, this implies that banks face a maturity transformation problem because they use short-term deposits and accumulated wealth to provide long-term credit. The standard case of one-period credit and no maturity transformation is thus recovered when $\alpha_{k}=0$.

Using this model we then analyse the quantitative implications of long-term lending following a positive technology shock. Our setup implies that long-term credit and maturity transformation dampen responses in consumption and investment to a technology shock. This effect arises because two mechanisms in our model reduce the procyclicality of banks' net worth and consequently weaken the financial accelerator.

The first mechanism relates to banks' balance sheets, where long-term credit implies that only a fraction of all loans is reset to reflect a higher price of capital after the shock. With long-term credit, good-producing firms therefore increase their credit demand by a smaller amount compared to the case of one-period contracts. This implies that banks' revenue and net-worth increase by less with long-term credit, which weakens the responses in consumption and investment.

The second mechanism stems from the fact that firms with long-term credit face a nonstate contingent fixed loan rate until capital is re-optimised. In comparison to a sequence of one-period loan contracts, firms are therefore better off with long-term credit because the oneperiod loan rate increases after a positive technology shock. This means that bank profit and net worth increase by less with long-term credit, thereby reducing the effect of the financial accelerator.

Another implication of our model is that the average deposit rate should be less persistent than the average loan rate. This follows from the fact that firms obtain credit at a fixed loan rate for the duration of a contract whereas depositors face a floating rate each period. Using data on US corporate bonds, we verify that this prediction is in line with empirical evidence as long-term corporate interest rates are indeed more persistent than the short-term deposit rate.

The remainder of the paper is structured as follows. Section 2 extends the simple RBC model with infrequent capital adjustments and analyses the implications of this assumption. This 
model is extended in Section 3 with a banking sector performing maturity transformation. We then explore the effects of long-term credit and maturity transformation following a technology shock in Section 4. Concluding comments are provided in Section 5.

\section{A standard RBC model with infrequent capital adjustments}

The aim of this section is to describe how a standard real business cycle (RBC) model can be extended to incorporate the idea that firms do not optimally choose capital in every period. We then show that this extension does not affect the dynamics of prices and aggregate variables in the model. This result holds under weak assumptions and generalises to a wide class of DSGE models. We proceed as follows; Sections 2.1 to 2.3 describe how we modify the standard RBC model, while the implications are analysed in Section 2.4.

\subsection{Households}

Consider a representative household which consumes $c_{t}$, provides labour $h_{t}$, and accumulates capital $k_{t}^{s}$. The contingency plans for $c_{t}, h_{t}$, and $i_{t}$ are determined by maximizing

$$
\mathbf{E}_{t} \sum_{j=0}^{\infty} \beta^{j}\left(\frac{\left(c_{t+j}-b c_{t+j-1}\right)^{1-\phi_{0}}-1}{1-\phi_{0}}+\phi_{2} \frac{h_{t+l}^{1+\phi_{1}}}{1+\phi_{1}}\right)
$$

subject to

$$
\begin{gathered}
c_{t}+i_{t}=h_{t} w_{t}+r_{t}^{k} k_{t}^{s} \\
k_{t+1}^{s}=(1-\delta) k_{t}^{s}+i_{t}-\frac{\kappa}{2}\left(\frac{i_{t}}{k_{t}^{s}}-\frac{i_{s s}}{k_{s s}^{s}}\right)^{2} k_{t}^{s}
\end{gathered}
$$

and the usual no-Ponzi game condition. The left-hand side of equation (2) lists expenditures on consumption and investment $i_{t}$, while the right-hand side describes the sources of income. We let $w_{t}$ denote the real wage and $r_{t}^{k}$ the real rental rate for capital services. Preferences are assumed to display internal habits if $b>0$ because habits in general improve the ability of DSGE models to reproduce various macroeconomic and financial moments (see for instance Campbell \& Cochrane (1999), Fuhrer (2000), and Christiano et al. (2005)). Capital depreciation is determined by $\delta$, while the capital accumulation equation includes standard quadratic 
adjustment costs to ensure relatively realistic investment dynamics. ${ }^{4}$ The Lagrange multipliers related to (2) and (3) are denoted by $\lambda_{t}$ and $q_{t} \lambda_{t}$, respectively.

\section{$2.2 \quad$ Firms}

We assume a continuum of firms indexed by $i \in[0,1]$ and owned by the households. Profit in each period is given by the difference between firms' output and costs, where the latter are composed of rental costs for capital $r_{t}^{k} k_{i, t}$ and the wage bill $w_{t} h_{i, t}$. Both costs are paid at the end of the period. We assume that output is produced from capital and labour according to a standard Cobb-Douglas production function

$$
y_{i, t}=a_{t} k_{i, t}^{\theta} h_{i, t}^{1-\theta}
$$

The aggregate level of productivity $a_{t}$ is assumed to evolve according to

$$
\log \left(a_{t}\right)=\rho_{a} \log \left(a_{t-1}\right)+\varepsilon_{t}^{a},
$$

where $\varepsilon_{t}^{a} \sim \mathcal{N} \mathcal{I D}\left(0, \sigma_{a}^{2}\right)$ and $\rho_{a} \in(-1,1)$.

The model has so far been fairly standard. We now depart from the typical RBC setup by assuming that firms can only choose their optimal capital level with probability $1-\alpha_{k}$ in every period. The probability $\alpha_{k} \in[0,1[$ is assumed to be the same for all firms and across time. This specification of lumpy investments has previously been adopted by Kiyotaki \& Moore (1997) and Sveen \& Weinke (2007) in the context of firm-specific capital. We depart from their setup by letting capital be homogenous across firms and traded in a competitive rental market. As in Kiyotaki \& Moore (1997) and Sveen \& Weinke (2007), capital remains constant for firms that cannot re-optimise. This reflects an implicit assumption that firms continuously make maintenance investments, which according to Doms \& Dunne (1998) constitute an important part of firms' investments. All firms are, however, allowed to choose how much labour to employ in every period as in the standard RBC model.

One way to rationalise our restriction on firms' ability to adjust capital is as follows. The

\footnotetext{
${ }^{4}$ The superscript in (3) is used to emphasize that we specify capital supply $k_{t}^{s}$, whereas the subscript $s s$ refers to the steady state.
} 
decision of a firm to purchase a new machine or to set up a new plant usually involves some fixed costs as typically assumed in the literature (see Thomas (2002), Khan \& Thomas (2003), among others). These fixed costs could be related to gathering information, decision making, training the workforce, etc. and imply that firms make lumpy investments. ${ }^{5}$ We do not attempt to model the exact nature of these costs and how firms choose which period to adjust capital, but the setup still captures the main macroeconomic implications of firms' infrequent changes in capital.

Our assumption on firms' ability to adjust their capital level implies that there are two types of firms in every period: i) a fraction $1-\alpha_{k}$ which potentially change their capital level and ii) the remaining fraction $\alpha_{k}$ which produce using a capital level chosen in the past. In a given period, all re-optimising firms choose the same level of capital $\widetilde{k}_{t}$ due to the absence of cross-sectional heterogeneity. By the same token, all firms that produce in period $t$ using capital chosen in period $t-j$ also demand the same level of labour, denoted $\widetilde{h}_{t \mid t-j}$ for $j=\{1,2, \ldots\}$. Hence, firms adjusting capital in period $t$ solve the problem

$$
\max _{\widetilde{k}} \mathbf{E}_{t} \sum_{j=0}^{\infty} \alpha_{k}^{j} \beta^{j} \frac{\lambda_{t+j}}{\lambda_{t}}\left[a_{t+j} \widetilde{k}_{t}^{\theta} \widetilde{h}_{t+j \mid t}^{1-\theta}-r_{t+j}^{k} \widetilde{k}_{t}-w_{t+j} \widetilde{h}_{t+j \mid t}\right] .
$$

We see that firms account for the fact that they might not adjust capital again for potentially many periods. The first-order condition for $\tilde{k}_{t}$ is given by

$$
\mathbf{E}_{t} \sum_{j=0}^{\infty} \alpha_{k}^{j} \beta^{j} \frac{\lambda_{t+j}}{\lambda_{t}}\left(a_{t+j} \theta \tilde{k}_{t}^{\theta-1} \widetilde{h}_{t+j \mid t}^{1-\theta}-r_{t+j}^{k}\right)=0 .
$$

If $\alpha_{k}>0$, then the optimal choice of capital depends on the discounted value of all future expected marginal products of capital and rental rates. Note also that the discount factor between periods $t$ and $t+j$ incorporates $\alpha_{k}^{j}$ which is the probability that the firm cannot adjust its level of capital for $j$ periods. If $\alpha_{k}=0$, equation (7) reduces to the standard case where the firm sets capital such that its current marginal product equals the current rental rate.

\footnotetext{
${ }^{5}$ See Hamermesh \& Pfann (1996), Cooper \& Haltiwanger (2006) and their references for empirical evidence on fixed costs in the investment process.
} 
The first-order condition for labour is

$$
h_{i, t}=\left(\frac{w_{t}}{a_{t}(1-\theta)}\right)^{-\frac{1}{\theta}} k_{i, t} \text { for } i \in[0,1]
$$

Here, we do not need to distinguish between optimising and non-optimising firms because all firms are allowed to optimally set their labour demand each period. We also note that the capital-labour ratio only depends on aggregate variables and is therefore identical for all firms.

\subsection{Market clearing and aggregation}

In equilibrium, the aggregate supply of capital must equal the capital demand of all firms, i.e.

$$
k_{t}^{s}=\int_{0}^{1} k_{i, t} d i
$$

A fraction of $1-\alpha_{k}$ firms choose $\tilde{k}_{t}$ in period $t$. The capital demand among firms not reoptimising is equal to the aggregate capital in period $t-1$ scaled by $\alpha_{k}$. This is because all firms face the same probability of being allowed to adjust capital. Market clearing in the rental market for capital is therefore given by

$$
k_{t}^{s}=\left(1-\alpha_{k}\right) \tilde{k}_{t}+\alpha_{k} k_{t-1}^{s}
$$

Note that $k_{t}^{s}=\tilde{k}_{t}$ when $\alpha_{k}=0$ and all firms are allowed to adjust their capital level in every period.

Market clearing in the labour market implies

$$
h_{t}=\int_{0}^{1} h_{i, t} d i
$$

and (8) therefore gives

$$
h_{t}=\left(\frac{w_{t}}{a_{t}(1-\theta)}\right)^{-\frac{1}{\theta}} k_{t}^{s} .
$$

Finally, the goods market clears when

$$
y_{t} \equiv \int_{0}^{1} y_{i, t} d i=c_{t}+i_{t} .
$$




\section{$2.4 \quad$ Implications of infrequent capital adjustments}

The parameter $\alpha_{k}$ determines the fraction of firms re-optimising capital in a given period, or equivalently the average number of periods $1 /\left(1-\alpha_{k}\right)$ that the $i$ 'th firm operates without adjusting its capital level. Nevertheless, the proposition below shows that the value of $\alpha_{k}$ does not have any business cycle implications for prices and aggregate variables in our model.

Proposition 1 The parameter $\alpha_{k}$ has no impact on the laws of motion for $c_{t}, i_{t}, h_{t}, w_{t}, r_{t}^{k}$, $k_{t}^{s}, \lambda_{t}, q_{t}$, and $a_{t}$.

Proof. The model consists of ten variables $c_{t}, i_{t}, h_{t}, w_{t}, r_{t}^{k}, k_{t}^{s}, \tilde{k}_{t}, \lambda_{t}, q_{t}, a_{t}$ and ten equations. The parameter $\alpha_{k}$ only enters in (7) and (10). The dynamics of $k_{t}^{s}$ follows from $\tilde{k}_{t}$ and the system can therefore be reduced to nine equations in nine variables. Note also that (12) implies $\tilde{k}_{t}^{\theta-1} \widetilde{h}_{t+j \mid t}^{1-\theta}=\left(\frac{w_{t+j}}{a_{t+j}(1-\theta)}\right)^{-\frac{1-\theta}{\theta}}$ which allow us to simplify the algebra. We need to show that the first-order condition for capital when $\alpha_{k}=0$ is equivalent to the first-order condition for capital when $\alpha_{k}>0$, i.e.

$$
\begin{aligned}
\forall t: a_{t} \theta\left(\frac{w_{t}}{a_{t}(1-\theta)}\right)^{-\frac{1-\theta}{\theta}} & =r_{t}^{k} \Longleftrightarrow \\
& \forall t: \mathbf{E}_{t} \sum_{j=0}^{\infty} \alpha_{k}^{j} \beta^{j} \frac{\lambda_{t+j}}{\lambda_{t}}\left(a_{t+j} \theta\left(\frac{w_{t+j}}{a_{t+j}(1-\theta)}\right)^{-\frac{1-\theta}{\theta}}-r_{t+j}^{k}\right)=0 .
\end{aligned}
$$

To show $\Longrightarrow$ we observe that $a_{t} \theta\left(\frac{w_{t}}{a_{t}(1-\theta)}\right)^{-\frac{1-\theta}{\theta}}=r_{t}^{k}$ implies that each of the elements in the infinite sum is equal to zero and so are the conditional expectations. To prove $\Longleftarrow$ we first lead the infinite sum by one period and multiply the expression by $\alpha_{k} \beta \frac{\lambda_{t+1}}{\lambda_{t}}>0$. This gives

$$
\mathbf{E}_{t+1}\left[\sum_{i=1}^{\infty} \alpha_{k}^{i} \beta^{i} \frac{\lambda_{t+i}}{\lambda_{t}}\left(a_{t+i} \theta\left(\frac{w_{t+i}}{a_{t+i}(1-\theta)}\right)^{-\frac{1-\theta}{\theta}}-r_{t+i}^{k}\right)\right]=0
$$

and by the law of iterated expectations

$$
\mathbf{E}_{t}\left[\sum_{i=1}^{\infty} \alpha_{k}^{i} \beta^{i} \frac{\lambda_{t+i}}{\lambda_{t}}\left(a_{t+i} \theta\left(\frac{w_{t+i}}{a_{t+i}(1-\theta)}\right)^{-\frac{1-\theta}{\theta}}-r_{t+i}^{k}\right)\right]=0
$$


Another way to express the infinite sum is

$$
\begin{gathered}
\mathbf{E}_{t}\left[a_{t} \theta\left(\frac{w_{t}}{a_{t}(1-\theta)}\right)^{-\frac{1-\theta}{\theta}}-r_{t}^{k}\right]+ \\
\mathbf{E}_{t}\left[\sum_{j=1}^{\infty} \alpha_{k}^{j} \beta^{j} \frac{\lambda_{t+j}}{\lambda_{t}}\left(a_{t+j} \theta\left(\frac{w_{t+j}}{a_{t+j}(1-\theta)}\right)^{-\frac{1-\theta}{\theta}}-r_{t+j}^{k}\right)\right]=0
\end{gathered}
$$

Using (14), this expression reduces to

$$
a_{t} \theta\left(\frac{w_{t}}{a_{t}(1-\theta)}\right)^{-\frac{1-\theta}{\theta}}=r_{t}^{k}
$$

as required.

The intuition behind this irrelevance proposition is as follows. When the capital supply is predetermined, it does not matter if a fraction of firms cannot change their capital level because the other firms have to demand the remaining capital to ensure equilibrium in the capital market. The fact that the capital-labour ratio is the same across firms further implies that aggregate labour demand is similar to the case where all firms can adjust capital. The aggregate output produced by firms is also unaffected due to the presence of constant returns to scale in the production function. Proposition 1 is therefore similar to the well-known result from microeconomics for a market in perfect competition and constant returns to scale, where only the aggregate production level can be determined but not the production level of individual firms. Accordingly, the implications of infrequent capital adjustments differ substantially from the well-known real effects of staggered nominal price contracts when specified as in Calvo (1983). The difference emerges because the friction with Calvo-contracts is imposed on firms' prices whereas we impose the same type of friction on quantities, i.e. firms' capital stock, in a setting where the scale of firms' production is irrelevant for aggregate output due to the Cobb-Douglas production function.

Proposition 1 is closely related to the work by Thomas (2002), Khan \& Thomas (2003), and Khan \& Thomas (2008), showing that non-convex adjustment costs and lumpy investments are quantitatively unimportant for the business cycle. The intuition they provide is broadly similar to ours, namely the importance of factor supply which originates from the households' smooth 
consumption profile across time. However, we emphasize two aspects where our result differs from previous work. Firstly, the friction in our model is different from the one considered by Khan and Thomas. Secondly, lumpy investments do affect the business cycle in the papers by Khan and Thomas but the effects are quantitatively irrelevant. Our result is therefore more extreme because we find that the considered friction does not have any effect on the business cycle.

The irrelevance result in Proposition 1 also relates to Sveen \& Weinke (2007) who impose the same constraint on firms' inability to change capital but combine it with firm-specific capital. They show that lumpy investments have macroeconomic implications, and that this friction in a linearized setting is equivalent to convex adjustment costs based on the change in the capital stock. Our proposition therefore helps to clarify that the assumption of firm-specific capital is vital for the results in Sveen \& Weinke (2007). Along similar lines, Bachmann et al. (2010) show that maintenance investments may help to explain the conditional heteroscedasticity in post-war US investments and therefore may have important macroeconomic implications.

It is also worth highlighting two other interesting economic implications of infrequent capital adjustments. Firstly, the distortion on firms' ability to change their capital level does not break the relation from the standard RBC model, where the marginal product of capital equals its rental price. In other words, the distortion in the capital market does not lead to any inefficiencies because the remaining part of the economy is sufficiently flexible to compensate for the imposed friction. Secondly, the infrequent capital adjustments give rise to firm heterogeneity because firms' capital levels depend on when they last re-optimised. This firm heterogeneity relates to the literature on firm-specific capital as in Sveen \& Weinke (2005), Woodford (2005), among others.

When proving Proposition 1 we only use three assumptions from our RBC model, besides the predetermined capital supply. Hence, the irrelevance result holds for a wide class of DSGE models. We state this observation in Corollary 1.

Corollary 1 Proposition 1 holds for a wide class of DSGE models with the following three properties:

1. Homogenous capital traded in a competitive rental market for capital 
3. The parameter $\alpha_{k}$ only enters into the equilibrium conditions for capital

Examples of DSGE models with these properties are models with sticky wages, monopolistic competition, investment adjustment costs to name just a few. ${ }^{6}$ The three most obvious ways to break the irrelevance of the infrequent capital adjustments can be inferred from (8). That is, if firms i) do not have a Cobb-Douglas production function with constant returns to scale, ii) are subject to firm-specific productivity shocks, or iii) face different wage levels due to imperfections in the labour market. ${ }^{7}$ Another way to break the irrelevance of infrequent capital adjustments is to make $\alpha_{k}$ affect the remaining part of the economy. In the next section we show how this can be accomplished by introducing a banking sector into the model.

\section{An RBC model with banks and maturity transformation}

This section incorporates a banking sector into the RBC model developed above. Here, we impose the standard assumption that firms need to borrow prior to financing their capital level. This requirement combined with infrequent capital adjustments generate a known demand for credit for several periods. We then assume that firms obtain this credit through a long-term contract with a fixed loan rate. Banks use one-period deposits from households and accumulated wealth (i.e. net worth) to meet this demand. As a result, banks face a maturity transformation problem because they use short-term deposits to provide long-term credit.

We should note that no attempt is made to prove the optimality of long-term credit contracts in our model or that they are preferred to a sequence of one-period loan contracts. That is, we simply take the presence of long-term credit for given and address its implications. Instead, we appeal to the existence of corporate bonds with multi-period durations as our empirical justification for analysing long-term credit contracts.

\footnotetext{
${ }^{6}$ Proprosition 1 also extends directly to models with sticky prices when this stickiness is introduced at the level of retail firms, which combine output from firms to a single CES composite as in Gertler \& Karadi (2011).

${ }^{7}$ The findings in Khan \& Thomas (2008) indicate that our irrelevance result may be quantitatively robust to the two first suggestions, as they allow for decreasing returns to scale in a Cobb-Douglas production function with firm-specific productivity shocks and find that lumpy investments only have small effects on the business cycle.
} 
Having outlined the novel feature of our model, we now turn to the details. The economy is assumed to have four groups of agents: i) households, ii) banks, iii) good-producing firms, and iv) capital-producing firms. The latter type of firms is standard in the literature and introduced to facilitate the aggregation (see for instance Bernanke et al. (1999)).

The interactions between the four types of agents are displayed in Figure 1. ${ }^{8}$ Households supply labour to the good-producing firms and make short-term deposits in banks. Banks use these deposits together with their own wealth to provide long-term credit to good-producing firms. These firms hire labour and use credit to obtain capital from the capital-producers who own the capital stock.

\section{$<$ Figure 1 about here $>$}

We proceed as follows. Sections 3.1 and 3.2 revisit the problems for the households and goodproducing firms when banks are present. Sections 3.3 and 3.4 are devoted to the behaviour of banks and the capital-producing firm, respectively. We end the section by listing market clearing conditions in Section 3.5.

\subsection{Households}

Each household is inhabited by workers and bankers. Workers provide labour $h_{t}$ to goodproducing firms and in exchange receive labour income $w_{t} h_{t}$. Each banker manages a bank and accumulates wealth which is eventually transferred to his household. It is assumed that a banker becomes a worker with probability $\alpha_{b}$ in each period, and only when this event occurs is the wealth of the banker transferred to the household. Each household postpones consumption from period $t$ to $t+1$ by making short-term deposits in banks. ${ }^{9}$ Deposits $b_{t}$ made in period $t$ are repaid at the beginning of period $t+1$ at the gross deposit rate $R_{t}$.

The households' preferences are as in Section 2.1. The lifetime utility function is maximised with respect to $c_{t}, b_{t}$, and $h_{t}$ subject to

$$
c_{t}+b_{t}=h_{t} w_{t}+R_{t-1} b_{t-1}+T_{t} .
$$

\footnotetext{
${ }^{8}$ For simplicity, Figure 1 does not show profit flows to households from firms and banks.

${ }^{9}$ As in Gertler \& Karadi (2011), it is assumed that a household is only allowed to deposit savings in banks owned by bankers from a different household. Additionally, it is assumed that within a household there is perfect consumption insurance.
} 
Here, $T_{t}$ denotes the net transfers of profits from firms and banks. Note that the households are not allowed to accumulate capital but are forced to postpone consumption through deposits in banks.

\subsection{Good-producing firms}

We impose the requirement on good-producing firms that they need credit to finance their capital stock. With infrequent capital adjustments we then find it reasonable to assume that firms rely on long-term credit provided by banks.

It is convenient in this setup to match the number of periods a firm cannot adjust its capital to the duration of its financial contract with the bank. That is, the financial contract lasts for all periods with no capital adjustment, and a new contract is signed whenever the firm is allowed to adjust capital. Since the latter event happens with probability $1-\alpha_{k}$ in each period, the exact maturity of a contract is not known ex ante. The average maturity of all existing contracts, however, is known and given by $\mathcal{D}=1 /\left(1-\alpha_{k}\right)$.

The specific obligations in the financial contract are as follows. A contract signed in period $t$ specifies the amount of capital $\widetilde{k}_{t}$ that the good-producing firm wants to finance for as long as it cannot re-optimise capital. Hence, the firm needs funding of $\widetilde{k}_{t} p_{t}^{k}$ throughout the contract where $p_{t}^{k}$ denotes the real price of capital. This credit is provided by the bank at a constant (net) interest rate $r_{t}^{L}$ during the contract. ${ }^{10}$ The financial contract is thus equivalent to a setup where the good-producing firm issues a perpetual bond with an embedded option, which allows the firm to redeem the bond when it re-optimises its capital level. Adopting this alternative interpretation, the bond is then bought by a bank in return for a fixed corporate yield. Due to the imposed structure on firms' inability to adjust their capital levels, the average duration across a sufficient number of perpetual bonds is therefore $\mathcal{D}$ quarters, making the loan rate $r_{t}^{L}$ comparable to the corporate yield of the same duration.

Physical capital is supplied by capital-producing firms in return for a fixed fee of $\omega p_{t}^{k}$ per capital unit during the contract. One can think of these expenditures as compensation to capital-producing firms for providing support and maintenance on the rented capital. It should be noted that our setup implies that physical capital exchanged between good- and capital-

\footnotetext{
${ }^{10}$ In the relationship between banks and good-producing firms, we do not consider any informational asymmetries, implying that firms cannot deviate from the signed contract or renegotiate it as in Hart \& Moore (1998).
} 
producing firms is valued based on the price of capital when a contract is signed. ${ }^{11}$ In this way, good-producing firms do not face uncertainty about the price of capital, and the interaction between good- and capital-producing firms therefore resembles a leasing relationship.

As in the standard RBC model, good-producing firms also hire labour which is combined with capital in a Cobb-Douglas production function. Costs attached to maintenance of the rented capital and the wage bill are paid after production takes place, implying that the demand for credit is uniquely associated with firms' capital level.

The assumptions above are summarised in the expression for profit $_{t+j \mid t}$, i.e. the profit in period $t+j$ for a firm that entered a financial contract in period $t$ :

$$
\pi_{t+j \mid t}=\underbrace{a_{t+j} \widetilde{k}_{t}^{\theta} h_{t+j \mid t}^{1-\theta}}_{\text {production revenue }}-\underbrace{r_{t}^{L} p_{t}^{k} \widetilde{k_{t}}}_{\text {interest on loan }}-\underbrace{\omega p_{t}^{k} \widetilde{k_{t}}}_{\text {cost of capital service }}-\underbrace{w_{t+j} h_{t+j \mid t}}_{\text {wage bill }}
$$

Note that all future cash-flows between the firm and the bank are determined with certainty for the duration of the contract. That is, the firm needs to fund $\widetilde{k}_{t} p_{t}^{k}$ which is done at the fixed loan rate $r_{t}^{L}$.

At the end of every period we assume that any profit is paid out as dividends to the households, meaning that good-producing firms enter the next period with zero wealth. ${ }^{12}$ Capital and labour decisions then follow by maximising the net present value of future profits. Using the households' stochastic discount factor, the first-order condition for the optimal level of capital $\widetilde{k_{t}}$ is given by

$$
\mathbf{E}_{t} \sum_{j=0}^{\infty} \alpha_{k}^{j} \beta^{j} \frac{\lambda_{t+j}}{\lambda_{t}}\left[\theta a_{t+j} \widetilde{k}_{t}^{\theta-1} h_{t+j \mid t}^{1-\theta}-\left(r_{t}^{L}+\omega\right) p_{t}^{k}\right]=0 .
$$

The price for financing one unit of capital throughout the contract is thus constant and given by $\left(r_{t}^{L}+\omega\right) p_{t}^{k}$. The first-order condition for the optimal choice of labour is exactly as in the standard RBC model, i.e. as in (8).

\footnotetext{
${ }^{11}$ This assumption is needed to ensure that good-producing firms borrow a constant amount every period like in fixed-rate mortgages or related corporate loan contracts. If we were instead to use the current price of capital, then the level of lending would fluctuate with the capital price and the contract would not resemble any real-life loan arrangement.

${ }^{12}$ This implies that any self-financing by good-producing firms is not possible. We impose this assumption to make our model similar to other papers in the literature (for instance Gertler \& Karadi (2011) where goodproducing firms always have zero profit) as this helps us to isolate the effects of long-term credit.
} 


\subsection{The banking sector}

Inspired by Gertler \& Karadi (2011), banks are introduced in the following way. The relationship between households and banks is characterized by an agency problem which constrains banks' leverage and in this way limits the credit provided by banks to good-producing firms. To avoid banks accumulating sufficient wealth to become independent of deposits, we assume that bankers retire with probability $\alpha_{b}$ each period, and when doing so, transfer wealth back to their respective households. To manage the transition of banking activities from old to new bankers, we introduce an insurance agency financed by a proportional tax on banks' profit. When a banker retires, the role of this agency is to create a new bank with an identical asset and liability structure and effectively guarantee the outstanding contracts of the old bank. This agency therefore ensures the existence of a representative bank and that the wealth of this bank is bounded with an appropriately calibrated tax rate. ${ }^{13}$

We next describe the balance sheet of the representative bank in Section 3.3.1 and present the agency problem in Section 3.3.2.

\subsubsection{Banks' balance sheets}

As mentioned earlier, the representative bank uses accumulated wealth $n_{t}$ and short-term deposits from households $b_{t}$ to provide credit to good-producing firms. This implies the following identity for the balance sheet of the representative bank

$$
l e n_{t} \equiv n_{t}+b_{t}
$$

where $l e n_{t}$ represents the amount of lending.

The bank's net wealth in period $t$ is therefore given by

$$
n_{t+1}=(1-\tau)\left[r e v_{t}-R_{t} b_{t}\right]
$$

where $\tau$ is the proportional tax rate and $r e v_{t}$ denotes revenue from lending to good-producing

\footnotetext{
${ }^{13}$ This setup differs slightly from Gertler \& Karadi (2011) who do not introduce an insurance agency but instead replace retired bankers by new bankers with a sufficiently low initial wealth. We prefer our setup because it ensures a representative bank and this greatly facilitates aggregation with long-term contracts.
} 
firms. The term $R_{t} b_{t}$ constitutes the value of deposits repaid to consumers. Combining the last two equations gives the following law of motion for net wealth

$$
n_{t+1}=(1-\tau)\left[r e v_{t}-R_{t} l e n_{t}+R_{t} n_{t}\right]
$$

The imposed structure for firms' inability to adjust capital implies simple expressions for $l e n_{t}$ and $r e v_{t}$. Starting with the total amount of lending in period $t$, we have

$$
\begin{aligned}
\text { len }_{t} & \equiv \int_{0}^{1} p_{i, t}^{k} k_{i, t} d i \\
& =\underbrace{\left(1-\alpha_{k}\right) p_{t}^{k} \widetilde{k}_{t}}_{\text {adjust in period } t}+\underbrace{\left(1-\alpha_{k}\right) \alpha_{k} p_{t-1}^{k} \widetilde{k}_{t-1}}_{\text {adjust in period } t-1}+\ldots \\
& =\left(1-\alpha_{k}\right) \sum_{j=0}^{\infty} \alpha_{k}^{j} p_{t-j}^{k} \widetilde{k}_{t-j}
\end{aligned}
$$

where simple recursions are easily derived. Similarly, for the total revenue we have

$$
\operatorname{rev}_{t}=\left(1-\alpha_{k}\right) \sum_{j=0}^{\infty} \alpha_{k}^{j} R_{t-j}^{L} p_{t-j}^{k} \widetilde{k}_{t-j}
$$

Here, $R_{t}^{L} \equiv 1+r_{t}^{L}$ is the gross loan rate. The intuition for these equations is as follows. A fraction $\left(1-\alpha_{k}\right)$ of the bank's lending and revenue in period $t$ relates to credit provided to adjusting firms in the same period. Likewise, a fraction $\left(1-\alpha_{k}\right) \alpha_{k}$ of lending and revenue relates to credit provided to firms that last adjusted capital in period $t-1$, and so on. For all contracts, the loans made $j$ periods in the past are repaid at the rate $R_{t-j}^{L}$. Thus, a large value of $\alpha_{k}$ makes the bank's balance sheet less exposed to changes in $R_{t}^{L}$ compared to small values of $\alpha_{k}$. The most important thing to notice, however, is that $\alpha_{k}$ affects the bank's lending and revenue and thereby its balance sheet, implying that the irrelevance proposition of infrequent capital adjustments in Section 2.4 does not hold for this model.

\subsubsection{The agency problem}

As in Gertler \& Karadi (2011), we assume that bankers can divert a fraction $\Lambda$ of their deposits and wealth at the beginning of the period and transfer it back to their corresponding households. The cost to bankers of diverting is that depositors can force them into bankruptcy and recover 
the remaining fraction $1-\Lambda$ of assets. Bankers therefore choose to stay in business whenever their associated value $V_{t}$ is greater than the benefit of diverting $\Lambda l e n_{t}$. This gives the following incentive constraint

$$
\begin{aligned}
& \overbrace{\text { banker's benefit }}^{V_{t}} \geq \overbrace{\text { banker's gain }}^{\Lambda l e n_{t}} \\
& \text { from running the bank from diverting }
\end{aligned}
$$

for households to have deposits in banks. The continuation value $V_{t}$ of a bank is given by

$$
V_{t}=\mathbf{E}_{t} \sum_{j=0}^{+\infty}\left(1-\alpha_{b}\right) \alpha_{b}^{j} \beta^{j+1} \frac{\lambda_{t+j+1}}{\lambda_{t}} n_{t+j+1}
$$

This expression reflects the idea that bankers attempt to maximise their expected wealth at the point of retirement when they transfer wealth to their household. Note that the discount factor in $(23)$ is adjusted by $\left(1-\alpha_{b}\right) \alpha_{b}^{j}$ to reflect the fact that retirement itself is stochastic and therefore could happen with positive probability in any period.

A sufficient condition ensuring that lending is profitable for the representative bank is given by

$$
\mathbf{E}_{t}\left[\lambda_{t+i+1} \sum_{j=0}^{\infty} \alpha_{k}^{j} p_{t+i-j}^{k} \widetilde{k}_{t+i-j}\left(R_{t+i-j}^{L}-R_{t+i}\right)\right] \geq 0 \text { for } i=0,1,2, \ldots
$$

That is, when the bank offers long-term credit of $p_{t+i-j}^{k} \widetilde{k}_{t+i-j}$, the average discounted lending rate $R_{t+i-j}^{L}$ during the contract should equal or exceed the discounted deposit rate $R_{t+i}$. This condition extends a similar requirement in Gertler \& Karadi (2011) to the case of long-term credit. When calibrating our model, we ensure that (24) holds.

The profitability of lending implies that the representative bank provides credit up to the limit allowed by the incentive constraint which holds with equality. Consequently, the amount of credit supplied by the bank is limited by its accumulated wealth through the relation

$$
l e n_{t}=l e v_{t} \times n_{t},
$$

where

$$
l e v_{t} \equiv \frac{x_{2, t}}{\frac{\Lambda}{1-\tau}-x_{1, t}}
$$


is the bank's leverage ratio. The two control variables $x_{1, t}$ and $x_{2, t}$ follow simple recursions derived in Appendix B.1.

\subsection{Capital-producing firms}

A representative capital-producing firm owns the capital stock and undertakes investments. The capital is rented to good-producing firms in return for service and maintenance fees determined when good-producing firms sign their financial contract. Hence, the capital-producing firm needs to keep track of its portfolio of signed contracts with good-producing firms in order to determine its income. For instance, a contract signed in period $t-4$ earns the capital-producing firm service and maintenance fees of $\omega p_{t-4}^{k} \widetilde{k}_{t-4}$.

More specifically, the net present value of profit for the capital-producing firm is given by

$$
\operatorname{profit}_{t}^{k}=\mathbf{E}_{t} \sum_{j=0}^{\infty} \beta^{j} \frac{\lambda_{t+j}}{\lambda_{t}}\left[\omega v_{t+j}-i_{t+j}\right] .
$$

Here, $v_{t}$ is a value aggregate given by

$$
v_{t} \equiv\left(1-\alpha_{k}\right) \sum_{j=0}^{\infty} \alpha_{k}^{j} p_{t-j}^{k} \widetilde{k}_{t-j}
$$

or equivalently

$$
v_{t}=\left(1-\alpha_{k}\right) p_{t}^{k} \widetilde{k}_{t}+\alpha_{k} v_{t-1}
$$

According to (27), the capital-producing firm obtains $\omega v_{t}$ from good-producing firms in service and maintenance fees and allocates resources to investments $i_{t}$. When maximizing profits, the firm must satisfy capital demand, i.e.

$$
k_{t}=\left(1-\alpha_{k}\right) \tilde{k}_{t}+\alpha_{k} k_{t-1}
$$

and the law of motion for aggregate capital with standard capital adjustment costs:

$$
k_{t+1}=(1-\delta) k_{t}+i_{t}-\frac{\kappa}{2}\left(\frac{i_{t}}{k_{t}}-\frac{i_{s s}}{k_{s s}}\right)^{2} k_{t}
$$

The optimisation of (27) is described in Appendix B.2. From this appendix we note that the 
Lagrange multiplier for (31), i.e. $q_{t}$, is the standard Tobin's Q and indicates a marginal change in profit following a marginal change in the next period capital $k_{t+1}$. On the other hand, the price of capital $p_{t}^{k}$ relates profit to the current capital $k_{t}$.

\subsection{Market clearing}

Market clearing conditions in the capital, labour, and good markets are similar to those derived in Section 2.3, and technology evolves according to the $\mathrm{AR}(1)$ process in (5). ${ }^{14}$

\section{Model implications}

This section explores the quantitative implications of maturity transformation and long-term credit in our model. We start by presenting our calibration in Section 4.1. To build some intuition for the key mechanisms of long-term credit within our model, we first analyse the simpler case without habits and capital adjustment costs in Section 4.2, while the analysis of the full model is deferred to Section 4.3. We end the section by providing empirical support for a key implication of long-term credit within our model.

\subsection{Calibration}

The model is calibrated to the post-war US economy in Table 1. Letting each period correspond to one quarter, we choose standard values for the capital share $\theta=0.30$, the coefficient of relative risk-aversion $\phi_{0}=1$, the depreciation rate $\delta=0.025$, and the discount factor $\beta=0.99$. The intensity of habits is set to $b=0.80$ based on the estimates in Justiniano \& Primiceri (2008). For the capital adjustment costs, we follow Khan \& Thomas (2003) and let $\kappa=2.2$. The steady state labour supply is normalised to one (via a restriction on $\phi_{2}$ ), and the inverse Frisch elasticity of labour supply $\phi_{1}$ is set to $1 / 3$. This degree of labour substitutability is slightly above the value estimated in Justiniano \& Primiceri (2008) but chosen to account for the fact that there are no wage rigidities in our model. Finally. the parameters determining the evolution of technology shocks are set to $\rho_{a}=0.979$ and $\sigma_{a}=0.0072$ as in King \& Rebelo (1999).

\footnotetext{
${ }^{14} \mathrm{~A}$ complete list of equations in the model is provided in Appendix B.3.
} 
There are three parameters which directly affect the behaviour of the banking sector: i) the fraction of banks' assets that can be diverted $\Lambda$, ii) the probability that a banker retires $\alpha_{b}$, and iii) the tax rate on banks' wealth $\tau$. To see how these parameters affect the model, note first that bank leverage in the steady state is given by

$$
l e v_{s s}=\frac{\beta\left(1-\alpha_{b}\right)}{\Lambda\left(1-\alpha_{b} \beta\right)}
$$

That is, leverage is low when bankers can divert and keep a relative large fraction of lending (high $\Lambda$ ), and vice versa. It is also straightforward to show that leverage controls the external finance premium as

$$
r_{s s}^{L}-r_{s s}=\frac{1}{l e v_{s s}}\left(\frac{1}{1-\tau}-\frac{1}{\beta}\right)
$$

As in Gertler \& Karadi (2011), we calibrate the three parameters for the banking sector to match a steady state external finance premium of 100 annualised basis points and a bank leverage of four. The parameter $\alpha_{k}$ does not affect the steady state value of leverage and the external finance premium, and is therefore left a free parameter to explore the implications of long-term credit and maturity transformation.

The size of the service and maintenance fees to capital-producing firms has only marginal effects in the model and we therefore simply let $\omega=0.0001 .{ }^{15}$ Throughout the paper, the model solution is computed by a standard log-linear approximation. ${ }^{16}$

$<$ Table 1 about here $>$

\subsection{Reduced model: implications of long-term credit and maturity transfor- mation}

Figure 2 displays impulse responses to a positive technology shock when omitting consumption habits and capital adjustment costs, i.e. $b=0$ and $\kappa=0$. In each graph, the continuous line shows the model with banks and one-period credit, i.e. the case where the average duration of contracts $\mathcal{D}$ is one quarter. Dashed lines correspond to two different calibrations of the model with long-term credit where we let $\mathcal{D}=4$ and $\mathcal{D}=16$.

\footnotetext{
${ }^{15}$ Simple algebra implies that in the steady state $v_{s s}=k_{s s} p_{s s}^{k}$ and $p_{s s}^{k}=(1-\beta(1-\delta)) /(\beta \omega)$, meaning that profit for capital-producing firms is $(1-\beta) / \beta$ and hence positive for $\beta<1$.

${ }^{16}$ All versions of the model are implemented in Dynare. Codes are available on request.
} 
We start by analysing the model with one-period loan contracts. As in the standard RBC model, a positive technology shock makes households temporarily richer and they therefore increase consumption. We also observe a higher one-period interest rate $r_{t}$ which further makes households increase bank deposits and smooth out the positive wealth effect across time. For good-producing firms, the higher productivity level makes it profitable to demand more capital and its price $p_{t}^{k}$ therefore increases. The higher price of capital leads capital-producing firms to expand investments, allowing them to provide more capital in future periods. For goodproducing firms, the desired higher capital level at a higher price greatly increases their credit demand. Although we see higher deposits and bank leverage, the expanding credit supply is insufficient to meet demand at the current loan rate $r_{t}^{L}$ which therefore increases. ${ }^{17}$ These combined effects generate an increase in banks' net worth $n_{t}$ as shown in Figure 2. In the periods following the shock, banks' financial position continues to improve and lending is further expanded, meaning that we obtain a financial accelerator effect in the sense of Bernanke et al. (1999). ${ }^{18}$

The business cycle implications of long-term credit can be considered by comparing the full and dashed lines in Figure 2. Increasing the average duration of loans to $\mathcal{D}=4$ and $\mathcal{D}=16$ quarters is seen to generate weaker responses in consumption and investment following the shock. Accordingly, our model predicts that long-term credit attenuates responses to a technology shock. This effect arises because two mechanisms reduce the procyclicality of banks' net worth with long-term credit. ${ }^{19}$

The first mechanism relates to banks' balance sheets where long-term credit $\left(\alpha_{k}>0\right)$ implies that only a fraction of all loans is reset to reflect a higher price of capital $p_{t}^{k}$ after the shock (see equations (19) - (21)). With long-term credit, good-producing firms therefore increase their credit demand by a smaller amount compared to the case with one-period contracts. As a result, banks' revenues and net-worth increase by less with long-term credit, and this contributes to weaker responses in consumption and investment.

\footnotetext{
${ }^{17}$ It is worth noting that the presence of financial frictions means that the one-period loan rate and the oneperiod deposit rate do not move in a one-to-one relationship.

${ }^{18}$ The impulse responses for banks' revenue, banks' net wealth, and deposits peak at around 50 periods after the shock and then gradually return to the steady state.

${ }^{19}$ This attenuating mechanism is thus similar to the one found in Carlstrom \& Fuerst (1997), although their setup differs from ours along several dimensions. However, if we were to allow firms to default then the procyclicality of firms profits in recessions has the potential to make banks' profit more pro-cyclical as well and could potentially reverse the attenuating mechanism. We leave this topic for future research.
} 
The second mechanism relates to the nature of the specified contract because each goodproducing firm faces a non-state contingent fixed loan rate until capital is re-optimised. That is, long-term credit implies loan stickiness. In comparison to a sequence of one-period loan contracts, good-producing firms are therefore better off with long-term credit when one-period loan rates increase and worse off when they fall. The one-period loan rate is closely linked to the marginal product of capital, which at least in our model is procyclical. As a result, goodproducing firms are worse off with long-term credit in recessions (low one-period loan rates) and better off during booms (high one-period loan rates), causing their profit to be more procyclical and consequentially making banks profit and net worth less procyclical. This channel therefore weakens the responses of consumption and investment because the lower procyclicality of banks' net worth reduces the impact of the financial accelerator. ${ }^{20}$

One way to illustrate this second channel is to look at the average loan rate across goodproducing firms, i.e.

$$
r_{t}^{L, a v g} \equiv\left(1-\alpha_{k}\right) \sum_{j=0}^{\infty} \alpha_{k}^{j} r_{t-j}^{L} .
$$

With long-term credit in Figure 2, we see a fall in the (marginal) loan rate $r_{t}^{L}$ in the first period after the shock. This fall is needed to make it profitable for the relatively few re-optimising good-producing firms to demand additional credit and finance more capital at the higher price level. In the second period after the shock, the price of capital falls slightly below its steady state level, allowing banks to increase their marginal loan rate $r_{t}^{L}$. This means that the average loan rate initially falls and then gradually returns to its steady state level. Overall, the average loan rate is therefore lower with long-term credit than the loan rate with one-period contracts in Figure 2, showing that good-producing firms are on average better off with long-term credit in an economic boom caused by a positive technology shock.

It is also worth noticing that the response of the deposit rate is highly dependent on the type of credit offered to good-producing firms. With one- and four-period contracts, we see the well-known effect from the standard RBC model where the deposit rate (i.e. the one-period real interest rate) increases with economic activity. This is in contrast to empirical evidence, showing a negative correlation between the real one-period interest rate and economic activity (see for instance King \& Rebelo (1999)). Interestingly, with long-term credit contracts of $\mathcal{D}=16$

\footnotetext{
${ }^{20}$ We are grateful to an anonymous referee for useful comments in relation to this channel.
} 
quarters, we find a fall in the deposit rate after the shock and hence the desired negative correlation between this rate and economic activity. This negative comovement arises because consumption peaks in the first period after the shock with $\mathcal{D}=16$ and then gradually returns to the steady state. This adjustment process is equivalent to negative consumption growth which from the standard Euler-equation $1=\mathbf{E}_{t}\left[\beta \frac{c_{t}}{c_{t+1}} R_{t}\right]$ implies negative deposit rates. On the other hand, with one- and four-period credit contracts, the consumption profile displays a hump-shaped response, and this explains why we here see a rise in the deposit rate following the shock.

$<$ Figure 2 about here $>$

\subsection{Full model: implications of long-term credit and maturity transforma- tion}

Figure 3 displays impulse responses to a positive technology shock when we relax the constraints on habits and capital adjustment costs. Due to habits, we now see a hump-shaped response in consumption and the size of the increase is smaller the longer the duration of the credit contract. Habits also affect the investment response which shows a much smaller expansion for one- and four-period contracts in comparison to the restricted model in the previous section. We also note that the investment response is even smaller with long-term contracts. ${ }^{21}$ As a result, long-term credit also attenuates the economic expansion following a positive technology shock in this richer version of our model.

Turning to the behaviour of the banking sector, we first note that the deposit rate now falls for all credit contracts. This effect is partly due to capital adjustment costs and partly due to habits. However, the response in the deposit rate is seen to be stronger the longer the duration of credit contracts. Capital adjustment costs also affect the price of capital as capital-producing firms now require a higher price $p_{t}^{k}$ to finance additional investments. As a result, we also see a sharper initial fall in the marginal loan rate to make it profitable for good-producing firms to obtain the required credit. Consequently, the fall in the average loan rate is therefore more pronounced in comparison to the model without habits and adjustment costs.

\footnotetext{
${ }^{21}$ With investment adjustment costs as in Christiano et al. (2005), we obtain broadly similar impulse responses, with the exception that investment displays a hump-shaped response which is weaker the longer the duration of the credit contract.
} 
Overall, we find that the responses to a technology shock in our model appear fairly robust as the presence of habits and capital adjustment costs do not change their qualitative nature.

\subsection{Empirical validation: persistency of deposit and loan rates}

Our setup allows firms to obtain credit at a fixed loan rate for the duration of a given contract. On the other hand, depositors face a floating rate which may change every period. Our model therefore suggests that the average deposit rate should be less persistent than the average loan rate. This section evaluates the empirical support for this key feature of our model by comparing the persistency of average deposit and loan rates in the US.

The average deposit rate in our model is equivalent to the three-month risk-free real interest rate. We therefore use the procedure by Stock \& Watson (1999) to compute the real threemonth interest rate as our measure for the average deposit rate in the US. ${ }^{22}$ Obtaining data on average loan rates of a given maturity is challenging. However, as previously mentioned, the financial contract in our model is equivalent to good-producing firms issuing bonds which banks buy in return for a fixed corporate yield until bonds are repaid when firms re-optimise their capital stock. We also note that our data on US corporate yields is derived from both new and outstanding corporate bonds of a given maturity, making the average loan rate with the same duration the most comparable variable in our model. ${ }^{23}$ Despite these close similarities, we should point out that the relationship between our loan rate and the corporate yield is not perfect, as the model-implied interest rate does not have a known maturity ex ante and ignores any default risk.

To evaluate the model implications for deposit and loan rates, we next consider an economy where the average frequency of investment matches the patterns documented in Doms \& Dunne (1998). Specifically, we set $\alpha_{k}$ to give a four year average investment cycle, which is in line with the interpretation by Sveen \& Weinke (2007) who let firms invest on average every $2-4$ years. We therefore report the persistency of the deposit rate and the four-year corporate yield in Table

\footnotetext{
${ }^{22}$ This procedure uses a regression model with four lags of quarterly consumer price inflation, the unemployment rate, and the yield on a three-month treasury bill to estimate inflation expectations in the next quarter. Subtracting this measure from the nominal interest rate then gives the real interest rate from 1948Q2 to 2011Q4. Where data is available (i.e. after 1997), our measure of inflation expectations closely matches the one implied by the difference between the nominal and real term structure in the US.

${ }^{23}$ The computation of the real corporate yield is outlined in Appendix B.4.
} 
2. Our measure of the US deposit rate is seen to have a first-order autocorrelation coefficient of 0.82 , while the four-year corporate yield is indeed more persistent with a persistency coefficient of 0.86 . The second row in Table 2 shows that our model largely matches these moments, as the corresponding persistency coefficients are 0.78 for the deposit rate and 0.96 for bond rate. Consequently, our model reproduces the stylised fact that long-term loan rates are more sticky than deposit rates in the US. ${ }^{24}$

The second part of Table 2 explores the robustness of this result by changing key model parameters. Excluding habits is seen to have a relatively large impact on the persistency in deposit and loan rates which increase to 0.98 and 0.995 , respectively. Although this degree of persistency exceeds empirical values, our model still matches the correct ordering in the persistency of the two interest rates. The subsequent rows in Table 2 show that ignoring capital adjustment costs $(\kappa=0)$, reducing the persistency in technology shocks $(\rho=0.9)$, lowering the labour substitution elasticity $\left(\phi_{1}=1\right)$, and lowering bank leverage $\left(\alpha_{b}=0.979\right)$ do not substantially change the persistency of deposit and loan rates in our model. Accordingly, our model only relies on habits to match the empirical persistency in deposit and loan rates while other model features seem to be of minor importance in this aspect.

\section{Conclusion}

This paper shows how to introduce a banking sector with long-term credit and maturity transformation into an otherwise standard DSGE model. Our key assumption is to consider the case where firms face a constant probability of being unable to reset their capital stock in every period. We first show that this restriction does not affect prices and aggregate quantities in a wide range of DSGE models. Importantly, the considered friction makes it reasonable to assume that firms demand long-term credit when we impose the standard requirement that firms borrow to finance their capital stock. As a result, banks face a maturity transformation problem because they use short-term deposits and accumulated wealth to provide long-term credit. In an RBC model featuring long-term contracts and banks, we then analyse the quantitative implications of long-term credit and maturity transformation following a positive technology shock. Our

\footnotetext{
${ }^{24}$ We also find empirical support for our model when considering the case where firms have access to longterm credit via an eight-year bond, as the persistency coefficient is 0.90 for the empirical yield and 0.97 for the corresponding model-implied interest rate.
} 
model suggests that the responses in consumption and investment are weaker the higher the degree of maturity transformation in the banking sector. Another implication of our model is that the average deposit rate is less persistent than the average loan rate. This follows from the fact that firms obtain credit at a fixed loan rate for the duration of a contract whereas depositors face a floating rate each period. Using corporate bond data for the US, we verify that this prediction is in line with empirical evidence as long-term corporate interest rates are found to be more persistent than the deposit rate.

Our way of incorporating maturity transformation is only a first step in analysing this topic in a dynamic stochastic general equilibrium setup. Adding nominal rigidities to our model and analysing nominal long-term credit contracts seem like natural extensions. ${ }^{25}$ Other interesting extensions could be to introduce extra financing options for firms, possibly by breaking the match between the duration of firms' exposure and their financial contract. This would also have the potential to create a time-varying maturity transformation problem in the banking sector. Studying higher-order effects and the impact of illiquidity and insolvency risks would also make for interesting extensions.

\footnotetext{
${ }^{25}$ This topic is partly explored in an earlier version of this paper (see Andreasen et al. (2012)).
} 


\section{References}

Aikman, D. \& Paustian, M. (2006), 'Bank capital, asset prices and monetary policy', Bank of England Working Paper no. 305 (305).

Akella, S. R. \& Greenbaum, S. J. (1992), 'Innovations in interest rates, duration transformation, and bank stock returns', Journal of Money, Credit and Banking 24, 27-42.

Andreasen, M. M., Ferman, M. \& Zabczyk, P. (2012), 'The business cycle implications of banks' maturity transformation', Bank of England Working Paper No. 446 .

Bachmann, R., Caballero, R. J. \& Engel, E. M. (2010), 'Aggregate Implications of Lumpy Investment: New Evidence and a DSGE Model', Working Paper .

Berger, A. N. \& Udell, G. F. (1992), 'Some evidence on the empirical significance of credit rationing', Journal of Political Economy 100(5), 1047-77.

Bernanke, B. S., Gertler, M. \& Gilchrist, S. (1999), The financial accelerator in a quantitative business cycle framework, in J. B. Taylor \& M. Woodford, eds, 'Handbook of Macroeconomics', Vol. 1 of Handbook of Macroeconomics, Elsevier, chapter 21, pp. 1341-1393.

Caballero, R. J. \& Engel, E. M. R. A. (1999), 'Explaining investment dynamics in u.s. manufacturing: A generalized (s,s) approach', Econometrica 67(4), 783-826.

Calvo, G. A. (1983), 'Staggered prices in a utility-maximizing framework', Journal of Monetary Economics 12(3), 383-398.

Campbell, J. Y. \& Cochrane, J. H. (1999), 'By force of habit: A consumption-based explanation of aggregate stock market behavior', Journal of Political Economy 107(2), 205-251.

Campello, M., Graham, J. \& Harvey, C. R. (2009), The real effects of financial constraints: Evidence from a financial crisis, NBER Working Papers 15552, National Bureau of Economic Research, Inc.

Carlstrom, C. T. \& Fuerst, T. S. (1997), 'Agency costs, net worth, and business fluctuations: A computable general equilibrium analysis', American Economic Review 87(5), 893-910. 
Chari, V., Christiano, L. J. \& Kehoe, P. J. (2008), Facts and myths about the financial crisis of 2008, Working Papers 666, Federal Reserve Bank of Minneapolis.

Chen, N.-K. (2001), 'Bank net worth, asset prices and economic activity', Journal of Monetary Economics 48, 415-436.

Christiano, L. J., Eichenbaum, M. \& Evans, C. L. (2005), 'Nominal rigidities and the dynamic effects of a shock to monetary policy', Journal of Political Economy 113(1), 1-45.

Cooper, R. W. \& Haltiwanger, J. C. (2006), 'On the nature of capital adjustment costs', Review of Economic Studies 73(3), 611-633.

Dell'Ariccia, G., Detragiache, E. \& Rajan, R. (2008), 'The real effect of banking crises', Journal of Financial Intermediation 17(1), 89-112.

den Heuvel, S. V. (2006), The bank capital channel of monetary policy, 2006 Meeting Papers 512, Society for Economic Dynamics.

Doms, M. \& Dunne, T. (1998), 'Capital adjustment patterns in manufacturing plants', Review of Economic Dynamics 1, 409-429.

Flannery, M. J. \& James, C. M. (1984), 'The effect of interest rate changes on the common stock returns of financial institutions', Journal of Finance 39(4), 1141-1153.

Fuhrer, J. C. (2000), 'Habit formation in consumption and its implications for monetary-policy models', The American Economic Review 90(3), 367-390.

Gambacorta, L. \& Mistrulli, P. E. (2004), 'Does bank capital affect lending behavior?', Journal of Financial Intermediation 13, 436-457.

Gerali, A., Neri, S., Sessa, L. \& Signoretti, F. M. (2009), Credit and banking in a dsge model of the euro area, Manuscript.

Gertler, M. (1992), 'Financial capacity and output fluctuations in an economy with multi-period financial relationships', The Review of Economic Studies 59, 455-472.

Gertler, M. \& Karadi, P. (2009), A model of unconventional monetary policy, mimeo, New York University. 
Gertler, M. \& Karadi, P. (2011), 'A model of unconventional monetary policy', Journal of Monetary Economics 58, 17-34.

Gertler, M. \& Kiyotaki, N. (2009), Financial intermediation and credit policy in business cycle analysis, mimeo, New York University.

Goodfriend, M. \& McCallum, B. T. (2007), 'Banking and interest rates in monetary policy analysis: A quantitative exploration', Journal of Monetary Economics 54(5), 1480-1507.

Hamermesh, D. S. \& Pfann, G. A. (1996), 'Adjustment costs in factor demand', Journal of Economic Literature 34(3), 1264-1292.

Hart, O. \& Moore, J. (1998), 'Default and renegotiation: A dynamic model of debt', Quarterly Journal of Economics CXIII(1), 1-41.

Hoggarth, G., Reis, R. \& Saporta, V. (2002), 'Costs of banking system instability: Some empirical evidence', Journal of Banking \& Finance 26(5), 825-855.

Justiniano, A. \& Primiceri, G. E. (2008), 'The time-varying volatility of macroeconomic fluctuations', American Economic Review 98(3), 604-641.

Khan, A. \& Thomas, J. K. (2003), 'Nonconvex factor adjustments in equilibrium business cycle models: Do nonlinearities matter?', Journal of Monetary Economics 50, 331-360.

Khan, A. \& Thomas, J. K. (2008), 'Idiosyncratic shocks and the role of nonconvexities in plant and aggregate investment dynamics', Econometrica 76(2), 395-436.

King, R. G. \& Rebelo, S. T. (1999), 'Resuscitating real business cycles', Handbook of Macroeconomics 1, 927-1007.

Kiyotaki, N. \& Moore, J. (1997), 'Credit cycles', Journal of Political Economy 105(2), 211-48.

Peek, J. \& Rosengren, E. S. (2000), 'Collateral damage: Effects of the japanese bank crisis on real activity in the united states', American Economic Review 90(1), 30-45.

Smets, F. \& Wouters, R. (2007), 'Shocks and frictions in us business cycles: A bayesian dsge approach', American Economic Review 97(3), 586-606. 
Smith, A. A. \& Wang, C. (2006), 'Dynamic credit relationships in general equilibrium', Journal of Monetary Economics 53, 847-877.

Stock, J. H. \& Watson, M. W. (1999), 'Business cycle fluctuations in US macroeconomic time series', Handbook of Macroeconomics 1, 3-64.

Sveen, T. \& Weinke, L. (2005), 'New perspectives on capital, sticky prices, and the taylor principle', Journal of Economic Theory 123(1), 21-39.

Sveen, T. \& Weinke, L. (2007), 'Lumpy investment, sticky prices, and the monetary transmission mechanism', Journal of Monetary Economics 54, 23-36.

Teranishi, Y. (2008), Optimal monetary policy under staggered loan contracts, IMES Discussion Paper Series 08-E-08, Institute for Monetary and Economic Studies, Bank of Japan.

Thomas, J. K. (2002), 'Is Lumpy Investment Relevant for the Business cycle', Journal of Political Economy 110(3), 508-534.

Vourougou, P. (1990), 'Interest-rate risk and the pricing of depository financial intermediary common stock', Journal of Banking and Finance 14, 803-820.

Woodford, M. (2005), 'Firm-specific capital and the new keynesian phillips curve', International Journal of Central Banking 1(2). 


\section{A A standard RBC model with infrequent capital adjustments}

\section{A.1 Households}

The representative household's problem can be summarised by the following Lagrangian:

$$
\begin{aligned}
\mathcal{L} & =\mathbf{E}_{t} \sum_{j=0}^{\infty} \beta^{j}\left(\frac{\left(c_{t+j}-b c_{t+j-1}\right)^{1-\phi_{0}}}{1-\phi_{0}}+\phi_{2} \frac{h_{t+j}^{1+\phi_{1}}}{1+\phi_{1}}\right) \\
& +\mathbf{E}_{t} \sum_{j=0}^{\infty} \beta^{j} \lambda_{t+j} \beta^{j} \lambda_{t+j}\left[h_{t+j} w_{t+j}+R_{t+j}^{k} k_{t+j}^{s}-c_{t+j}-i_{t+j}\right] \\
& +\mathbf{E}_{t} \sum_{j=0}^{+\infty} \beta^{j} q_{t+j} \lambda_{t+j}\left[(1-\delta) k_{t+j}^{s}+i_{t+j}-\frac{\kappa}{2}\left(\frac{i_{t+j}}{k_{t+j}^{s}}-\frac{i_{s s}}{k_{s s}^{s}}\right)^{2} k_{t+j}^{s}-k_{t+1+j}^{s}\right]
\end{aligned}
$$

where $\lambda_{t}$ and $q_{t}$ are Lagrange multipliers. The first order conditions are:

i Consumption, $c_{t}$ :

$$
\lambda_{t}=\mathbf{E}_{t}\left[\frac{1}{\left(c_{t}-b c_{t-1}\right)^{\phi_{0}}}-\frac{\beta b}{\left(c_{t+1}-b c_{t}\right)^{\phi_{0}}}\right]
$$

ii Labour, $h_{t}$ :

$$
\phi_{2} h_{t}^{\phi_{1}}=\lambda_{t} w_{t}
$$

iii Physical capital stock, $k_{t+1}^{s}$ :

$$
q_{t}=\mathbf{E}_{t}\left[\beta \frac{\lambda_{t+1}}{\lambda_{t}}\left(r_{t+1}^{k}+q_{t+1}(1-\delta)+\kappa\left(\frac{i_{t+1}}{k_{t+1}^{s}}-\frac{i_{s s}}{k_{s s}^{s}}\right) \frac{i_{t+1}}{k_{t+1}^{s}}-\frac{\kappa}{2}\left(\frac{i_{t+1}}{k_{t+1}^{s}}-\frac{i_{s s}}{k_{s s}}\right)^{2}\right)\right]
$$

\section{A.2 Firms}

Net present value of profit reads

$$
\mathbf{E}_{t} \sum_{j=0}^{\infty} \beta^{j} \frac{\lambda_{t+j}}{\lambda_{t}}\left(a_{t+j} k_{i, t+j}^{\theta} h_{i, t+j}^{1-\theta}-R_{t+j}^{k} k_{i, t+j}-w_{t+j} h_{i, t+j}\right) .
$$

This problem is divided in two steps. We first derive the $i^{\text {th }}$ firm's demand of labour, which takes the standard form since labour is optimally chosen in every period. In the second step, we derive the optimal value of capital $\widetilde{k}_{i, t}$ for firms that are able to adjust capital in period $t$.

\section{i Labour, $h_{t}$ :}

In every period $t+j$, for $j=0,1,2, \ldots$, all firms are allowed to adjust their labour demand, implying

$$
h_{i, t+j}=\left(\frac{w_{t+j}}{a_{t+j}(1-\theta)}\right)^{-\frac{1}{\theta}} k_{i, t+j} .
$$


The period $t+j$ demand for labour for a firm that last re-optimised in period $t, \tilde{h}_{i, t+j \mid t}$, is given by

$$
\tilde{h}_{i, t+j \mid t}=\left(\frac{w_{t+j}}{a_{t+j}(1-\theta)}\right)^{-\frac{1}{\theta}} \widetilde{k}_{i, t}
$$

ii Capital, $\widetilde{k}_{t}$ :

A firm adjusting capital in period $t$ chooses $\widetilde{k}_{i, t}$ to maximise the present discounted value of profits. This firm therefore solves

$$
\max _{\widetilde{k}_{i, t}} \mathbf{E}_{t} \sum_{j=0}^{\infty} \alpha_{k}^{j} \beta^{j} \frac{\lambda_{t+j}}{\lambda_{t}}\left(a_{t+j} \widetilde{k}_{i, t}^{\theta} \widetilde{h}_{i, t+j \mid t}^{1-\theta}-R_{t+j}^{k} \widetilde{k}_{i, t}-w_{t+j} h_{i, t+j \mid t}\right)
$$

Using the demand for labour derived above, the optimality condition associated with the capital choice for firm $i$ can be written as

$$
\mathbf{E}_{t} \sum_{l=0}^{\infty}\left(\alpha_{k} \beta\right)^{j} \frac{\lambda_{t+j}}{\lambda_{t}}\left(a_{t+j} \theta\left(\frac{w_{t+j}}{a_{t+j}(1-\theta)}\right)^{-\frac{1-\theta}{\theta}}-R_{t+j}^{k}\right)=0
$$

\section{B An RBC model with banks and maturity transformation}

\section{B.1 Recursions for $x_{1, t}$ and $x_{2, t}$}

The expected discounted value of bank equity $V_{t}$ can be expressed as

$$
\begin{aligned}
V_{t} & =\mathbf{E}_{t} \sum_{i=0}^{\infty}\left(1-\alpha_{b}\right) \alpha_{b}^{i} \beta^{i+1} \frac{\lambda_{t+i+1}}{\lambda_{t}}(1-\tau)\left[\text { rev }_{t+i}-R_{t+i} \text { len }_{t+i}+R_{t+i} n_{t+i}\right] \\
& =(1-\tau)\left\{l e n_{t}\left(\mathbf{E}_{t} \sum_{i=0}^{\infty}\left(1-\alpha_{b}\right) \alpha_{b}^{i} \beta^{i+1} \frac{\lambda_{t+i+1}}{\lambda_{t}}\left[\frac{r e v_{t+i}}{l e n_{t}}-R_{t+i} \frac{\operatorname{len}_{t+i}}{l e n_{t}}\right]\right)\right. \\
& \left.+n_{t}\left(\mathbf{E}_{t} \sum_{i=0}^{\infty}\left(1-\alpha_{b}\right) \alpha_{b}^{i} \beta^{i+1} \frac{\lambda_{t+i+1}}{\lambda_{t}} \frac{R_{t+i} n_{t+i}}{n_{t}}\right)\right\} \\
& =(1-\tau)\left[l e n_{t} x_{1, t}+n_{t} x_{2, t}\right]
\end{aligned}
$$

where we have defined

$$
\begin{gathered}
x_{1, t} \equiv \mathbf{E}_{t} \sum_{i=0}^{\infty}\left(1-\alpha_{b}\right) \alpha_{b}^{i} \beta^{i+1} \frac{\lambda_{t+i+1}}{\lambda_{t}}\left[\frac{r e v_{t+i}}{l e n_{t}}-R_{t+i} \frac{l e n_{t+i}}{l e n_{t}}\right] \\
x_{2, t} \equiv \mathbf{E}_{t} \sum_{i=0}^{\infty}\left(1-\alpha_{b}\right) \alpha_{b}^{i} \beta^{i+1} \frac{\lambda_{t+i+1}}{\lambda_{t}} \frac{R_{t+i} n_{t+i}}{n_{t}}
\end{gathered}
$$

Straightforward algebra then implies the following recursions:

$$
x_{1, t}=\mathbf{E}_{t}\left(1-\alpha_{b}\right) \beta \frac{\lambda_{t+1}}{\lambda_{t}}\left[\frac{r e v_{t}}{l e n_{t}}-R_{t}\right]+\mathbf{E}_{t}\left[\alpha_{b} \beta x_{1, t+1} \frac{l e n_{t+1}}{l e n_{t}} \frac{\lambda_{t+1}}{\lambda_{t}}\right]
$$




$$
x_{2, t}=\left(1-\alpha_{b}\right) \mathbf{E}_{t}\left[\beta \frac{\lambda_{t+1}}{\lambda_{t}}\right] R_{t}+\mathbf{E}_{t}\left[x_{2, t+1} \alpha_{b} \beta \frac{\lambda_{t+1}}{\lambda_{t}} \frac{n_{t+1}}{n_{t}}\right]
$$

\section{B.2 First-order conditions for capital-producing firms}

The Lagrange function reads:

$$
\begin{aligned}
\mathcal{L} & =\mathbf{E}_{t} \sum_{j=0}^{+\infty} \beta^{j} \frac{\lambda_{t+j}}{\lambda_{t}}\left[\omega v_{t+j}-i_{t+j}\right] \\
& +\mathbf{E}_{t} \sum_{j=0}^{+\infty} \beta^{j} \frac{\lambda_{t+j}}{\lambda_{t}} u_{1, t+j}\left[\left(1-\alpha_{k}\right) \widetilde{k}_{t+j} p_{t+j}^{k}+\alpha_{k} v_{t-1+j}-v_{t+j}\right] \\
& +\mathbf{E}_{t} \sum_{j=0}^{+\infty} \beta^{j} \frac{\lambda_{t+j}}{\lambda_{t}} q_{t+j}\left[(1-\delta) k_{t+j}+i_{t+j}-\frac{\kappa}{2}\left(\frac{i_{t+j}}{k_{t+j}}-\frac{i_{s s}}{k_{s s}}\right)^{2} k_{t+j}-k_{t+j+1}\right] \\
& +\mathbf{E}_{t} \sum_{j=0}^{+\infty} \beta^{j} \frac{\lambda_{t+j}}{\lambda_{t}}\left(-u_{3, t+j}\right)\left[\left(1-\alpha_{k}\right) \tilde{k}_{t+j}+\alpha_{k} k_{t-1+j}-k_{t+j}\right]
\end{aligned}
$$

The first-order conditions are:

i. The value-aggregate $v_{t}$ :

$$
u_{1, t}=\omega+E_{t}\left[\beta \frac{\lambda_{t+1}}{\lambda_{t}} u_{1, t+1} \alpha_{k}\right]
$$

ii. Investment $i_{t}$ :

$$
1=q_{t}\left(1-\kappa_{2}\left(\frac{i_{t}}{k_{t}}-\frac{i_{s s}}{k_{s s}}\right)\right)+E_{t}\left[\beta \frac{\lambda_{t+1}}{\lambda_{t}} q_{t+1} \kappa_{1}\left(\frac{i_{t+1}}{i_{t}}-1\right) \frac{i_{t+1}^{2}}{i_{t}^{2}}\right]
$$

iii. Capital $k_{t}$ :

$$
\begin{aligned}
q_{t}-E_{t}\left[\beta \frac{\lambda_{t+1}}{\lambda_{t}} u_{3, t+1}\right] & =E_{t}\left[\beta \frac{\lambda_{t+1}}{\lambda_{t}} q_{t+1}\left((1-\delta)-\frac{\kappa_{2}}{2}\left(\frac{i_{t+1}}{k_{t+1}}-\frac{i_{s s}}{k_{s s}}\right)^{2}+\kappa_{2}\left(\frac{i_{t+1}}{k_{t+1}}-\frac{i_{s s}}{k_{s s}}\right) \frac{i_{t+1}}{k_{t+1}}\right)\right] \\
& -E_{t}\left[\beta^{2} \frac{\lambda_{t+2}}{\lambda_{t}} u_{3, t+2} \alpha_{k}\right]
\end{aligned}
$$

iv. Capital for optimising firms $\tilde{k}_{t}$ :

$$
u_{1, t} p_{t}^{k}=u_{3, t}
$$




\section{B.3 Model summary}

Households:
1) $\lambda_{t}=E_{t}\left[\left(c_{t}-b c_{t-1}\right)^{-\phi_{0}}-\beta b\left(c_{t+1}-b c_{t}\right)^{-\phi_{0}}\right]$
2) $1=E_{t}\left[\beta \frac{\lambda_{t+1}}{\lambda_{t}} R_{t}\right]$
3) $\phi_{2} h_{t}^{\phi_{1}}=\lambda_{t} w_{t}$

Good-producing firms:
4) $h_{t}=\left(\frac{w_{t}}{a_{t}(1-\theta)}\right)^{-\frac{1}{\theta}} k_{t}$
5) $z_{1, t}=\left(r_{t}^{L}+\omega\right) p_{t}^{k} z_{2, t}$
6) $z_{1, t}=\theta a_{t}\left(\frac{w_{t}}{a_{t}(1-\theta)}\right)^{-\frac{1-\theta}{\theta}}+E_{t}\left[\frac{\lambda_{t+1}}{\lambda_{t}} z_{1, t+1} \alpha_{k} \beta\right]$
7) $\left.z_{2, t}=1+E_{t}\left[\frac{\lambda_{t+1}}{\lambda_{t}} \beta \alpha_{k}\right) z_{2, t+1}\right]$
8) $\quad k_{t}=\left(1-\alpha_{k}\right) \tilde{k}_{t}+\alpha_{k} k_{t-1}$

The banking sector:
9) $\quad n_{t+1}=(1-\tau)\left[\right.$ rev $_{t}-R_{t}$ len $\left.n_{t}+R_{t} n_{t}\right]$
10) $r e v_{t}=\left(1-\alpha_{k}\right) R_{t}^{L} p_{t}^{k} \widetilde{k}_{t}+\alpha_{k} r e v_{t-1}$
11) len $_{t}=\left(1-\alpha_{k}\right) p_{t}^{k} \widetilde{k}_{t}+\alpha_{k} l e n_{t-1}$
12) $l e v_{t} \equiv \frac{l e n_{t}}{n_{t}}$
13) $\frac{\operatorname{len} t}{n_{t}}=\frac{n_{t} x_{2, t}}{\frac{\Lambda}{1-\tau}-x_{1, t}}$
14) $x_{1, t}=E_{t}\left(1-\alpha_{b}\right) \beta^{1} \frac{\lambda_{t+1}}{\lambda_{t}}\left[\frac{r e v_{t}}{\text { lent }_{t}}-R_{t}\right]+E_{t}\left[\alpha_{b} \beta x_{1, t+1} \frac{\text { len }_{t+1}}{\text { lent }_{t}} \frac{\lambda_{t+1}}{\lambda_{t}}\right]$
15) $x_{2, t}=\left(1-\alpha_{b}\right) E_{t}\left[\beta \frac{\lambda_{t+1}}{\lambda_{t}}\right] R_{t}+E_{t}\left[x_{2, t+1} \alpha_{b} \beta \frac{\lambda_{t+1}}{\lambda_{t}} \frac{n_{t+1}}{n_{t}}\right]$

Capital-producing firms:
16) $k_{t+1}=(1-\delta) k_{t}+i_{t}-\frac{\kappa}{2}\left(\frac{i_{t}}{k_{t}}-\frac{i_{s s}}{k_{s s}}\right)^{2} k_{t}$
17) $u_{1, t}=\omega+E_{t}\left[\beta \frac{\lambda_{t+1}}{\lambda_{t}} u_{1, t+1} \alpha_{k}\right]$
18) $1=q_{t}\left(1-\kappa_{2}\left(\frac{i_{t}}{k_{t}}-\frac{i_{s s}}{k_{s s}}\right)\right)$
19) $q_{t}-E_{t}\left[\beta \frac{\lambda_{t+1}}{\lambda_{t}} u_{3, t+1}\right]=E_{t}\left[\beta \frac{\lambda_{t+1}}{\lambda_{t}} q_{t+1}\left((1-\delta)-\frac{\kappa}{2}\left(\frac{i_{t+1}}{k_{t+1}}-\frac{i_{s s}}{k_{s s}}\right)^{2}+\kappa\left(\frac{i_{t+1}}{k_{t+1}}-\frac{i_{s s}}{k_{s s}}\right) \frac{i_{t+1}}{k_{t+1}}\right)\right]$ $-E_{t}\left[\beta^{2} \frac{\lambda_{t+2}}{\lambda_{t}} u_{3, t+2} \alpha_{k}\right]$
20) $u_{1, t} p_{t}^{k}=u_{3, t}$
21) $v_{t}=\left(1-\alpha_{k}\right) \widetilde{k}_{t} p_{t}^{k}+\alpha_{k} v_{t-1}$

Market clearing conditions:

22) $y_{t}=a_{t} k_{t}^{\theta} h_{t}^{1-\theta}$

23) $y_{t}=c_{t}+i_{t}$

Exogenous process:

24) $\log a_{t}=\rho_{a} \log a_{t-1}+\varepsilon_{t}^{a}$

The 24 variables in the system are:

$\lambda_{t}, c_{t}, R_{t}, h_{t}, w_{t}, k_{t}, z_{1, t}, z_{2, t}, p_{t}^{k}, \tilde{k}_{t}$,

$n_{t}$, rev $v_{t}, R_{t}^{L}$, len $_{t}$, lev $_{t}, x_{1, t}, x_{2, t}, i_{t}, u_{1, t}, q_{t}, u_{3, t}, a_{t}, v_{t}, y_{t}$. 


\section{B.4 The real corporate term structure data}

We obtain nominal corporate yields of various maturities ( 6 buckets spanning $1-15+$ years) from Global Financial Data. For a given maturity, those are based on investment grade corporate bonds (AAA to BBB) with the average grade between AA and A, due to the relative paucity of AAA bonds. The data include both newly issued bonds as well as those issued in the past, and are rebalanced annually to ensure that the maturity of the included instruments lies within the relevant buckets. The data are monthly from 1996M12 to 2012M2 and we compute quarterly values by averaging over the quarter. Similar results are obtained by using end-quarter values. We adjust the nominal corporate yields using measures of inflation expectations extracted from the US nominal and real term structure as provided by McCulloch. For buckets spanning several years we simply assume that the maturity is the average of the start and end date (e.g. we would consider the 3-5 year bucket to consist of bonds of a 4-year maturity) and subtract the corresponding inflation expectation to obtain the real corporate yield. The McCulloch yield curves are available from 1997M1 to 2009M10, leaving us with quarterly values for real corporate yields from 1997Q1 to 2009Q3. 
Table 1: Calibration

\begin{tabular}{cccc}
\hline \hline & & & \\
$\beta$ & 0.99 & $\Lambda$ & 0.22 \\
$b$ & 0.80 & $\alpha_{b}$ & 0.92 \\
$\phi_{0}$ & 1 & $\tau$ & 0.02 \\
$\phi_{1}$ & 0.33 & $\delta$ & 0.025 \\
$\theta$ & 0.30 & $\rho_{a}$ & 0.979 \\
$\kappa$ & 2.2 & $\sigma_{a}$ & 0.0072 \\
$\alpha_{k}$ & free & $\omega$ & 0.0001 \\
\hline \hline
\end{tabular}

Table 2: Persistency of deposit and loan rates

This table reports the first-order autocorrelation coefficient for the real deposit rate (three-month riskfree rate) and a four year real corporate bond yield in the US. The corresponding model-implied moments are the real deposit rate and the average loan rate.

\begin{tabular}{l|cc}
\hline \hline & deposit rate & 4-year corporate bond yield \\
\hline Data & 0.82 & 0.86 \\
Model & 0.78 & 0.97 \\
Robustness: & & \\
No habits $(b=0)$ & 0.98 & 0.995 \\
No capital adjustment costs $(\kappa=0)$ & 0.78 & 0.97 \\
Lower technology persistency $(\rho=0.90)$ & 0.79 & 0.96 \\
Lower labour substitution elasticity $\left(\phi_{1}=1.0\right)$ & 0.70 & 0.95 \\
Lower bank leverage of $3\left(\alpha_{b}=0.979\right)$ & 0.76 & 0.95 \\
\hline \hline
\end{tabular}


Figure 1: RBC model with banks and maturity transformation

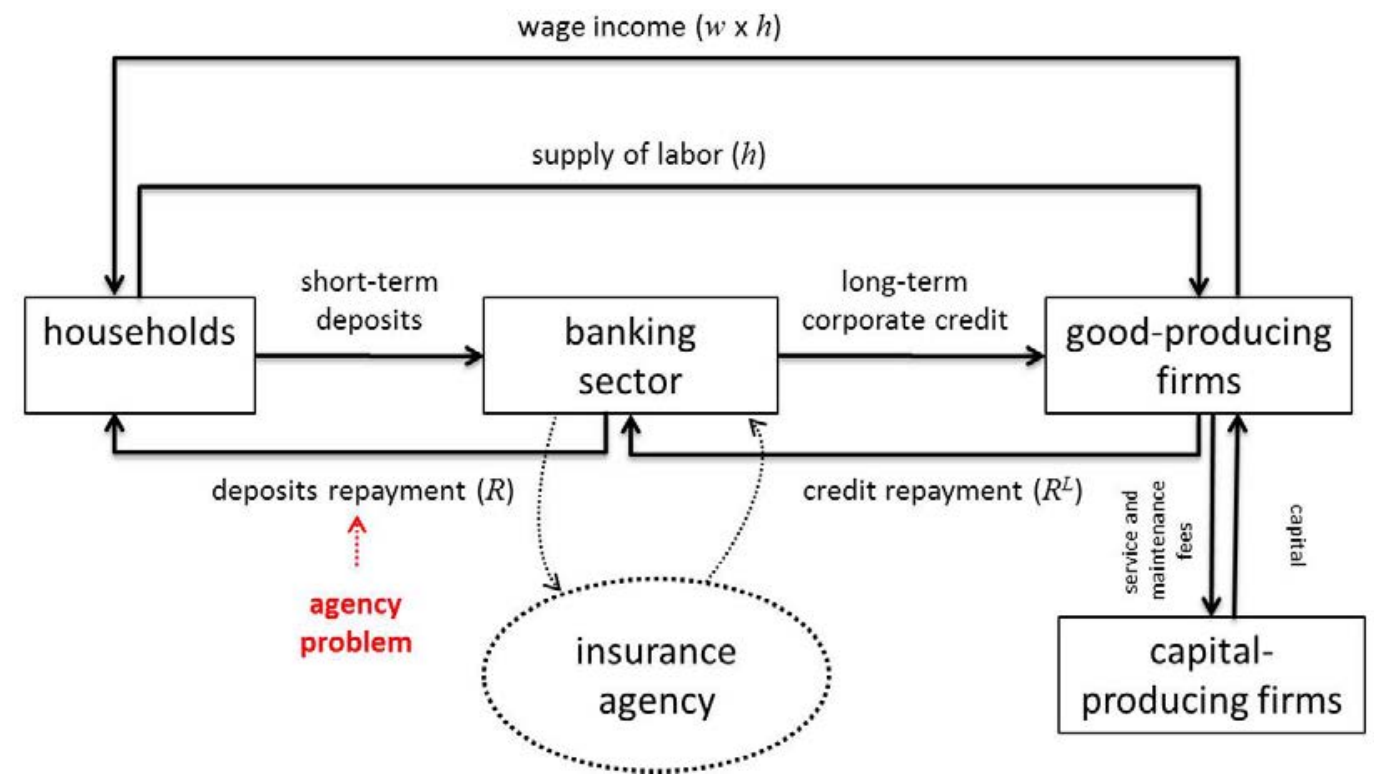


Figure 2: Reduced model: Impulse responses to a positive technology shock
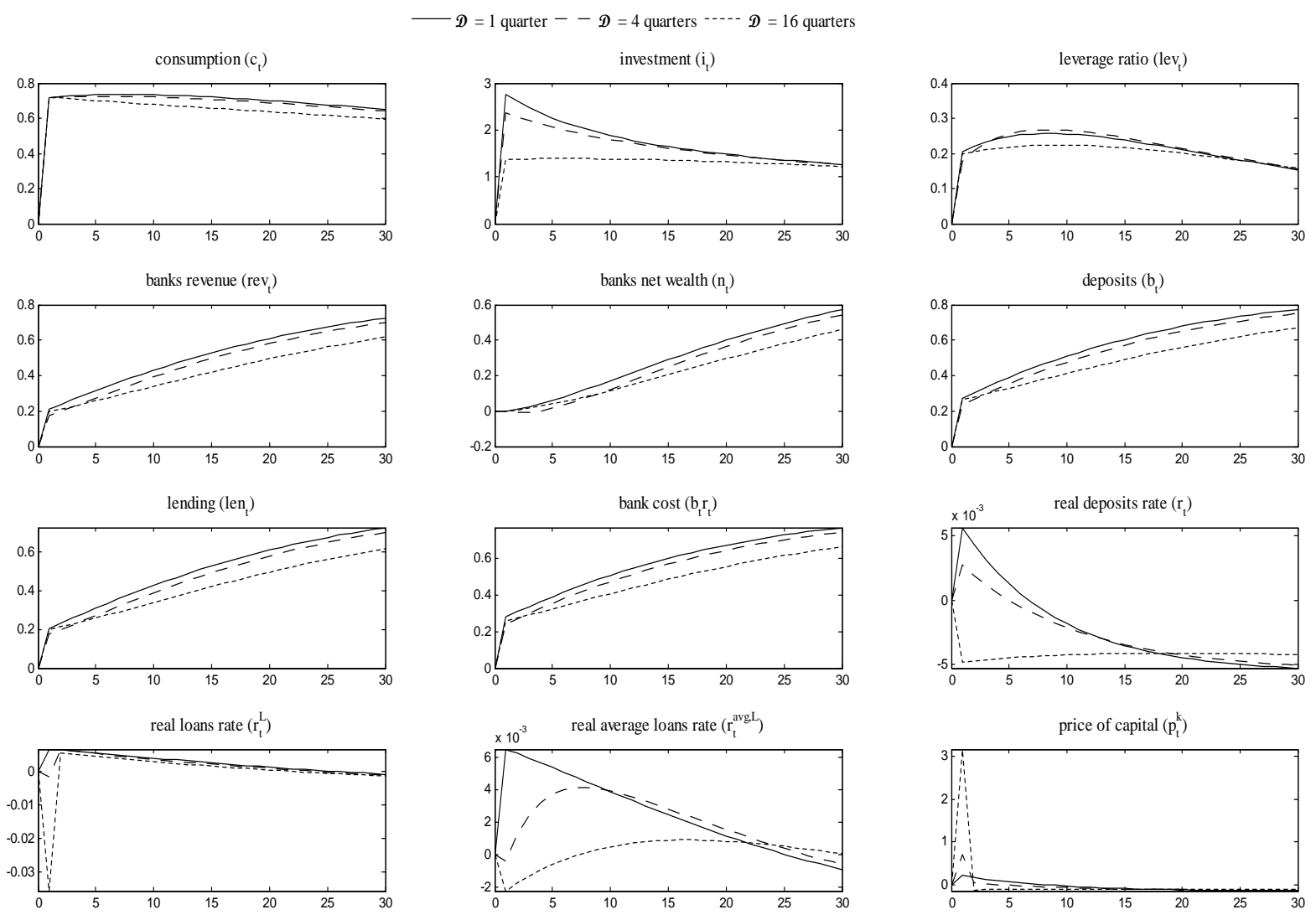

Notes: Impulse response to a one-standard deviation positive shock to technology. In each graph the vertical axis measures percentage deviation from the deterministic steady state of the respective variable, whereas the horizontal axis measures quarters after the shock hits. 
Figure 3: Full model: Impulse responses to a positive technology shock

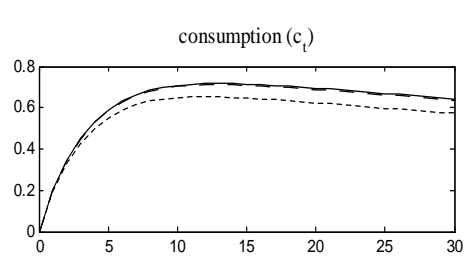

$-\mathfrak{D}=1$ quarter $--\mathfrak{D}=4$ quarters $-\cdots \cdot-16$ quarters
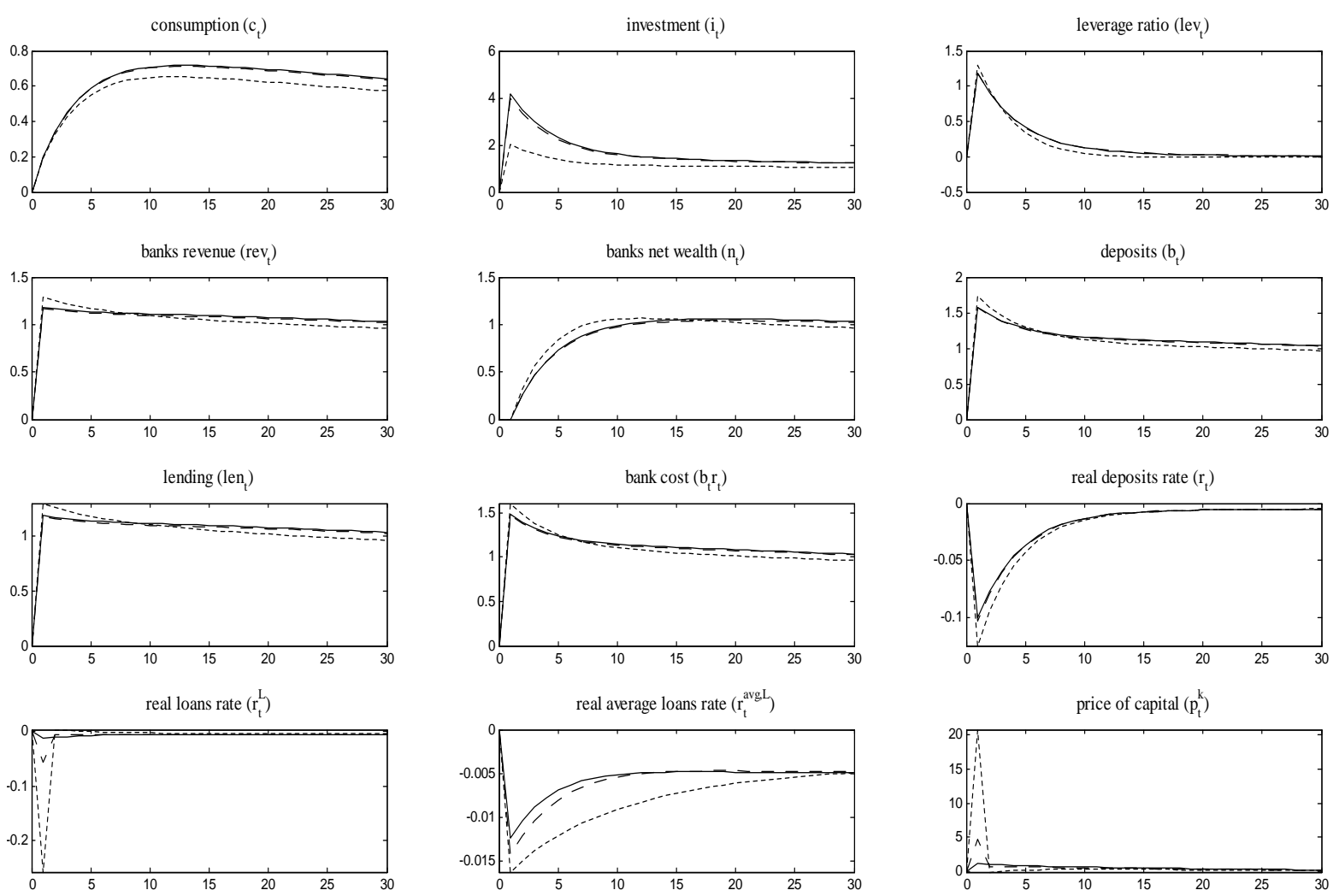

Notes: Impulse response to a one-standard deviation positive shock to technology. In each graph the vertical axis measures percentage deviation from the deterministic steady state of the respective variable, whereas the horizontal axis measures quarters after the shock hits. 